\title{
Aqueous enzyme assisted oil extraction from oilseeds and emulsion de- emulsifying methods: a review
}

Article

Accepted Version

Mat Yusoff, M., Gordon, M. and Niranjan, K. (2014) Aqueous enzyme assisted oil extraction from oilseeds and emulsion deemulsifying methods: a review. Trends in Food Science and Technology, 41 (1). pp. 60-82. ISSN 0924-2244 doi: https://doi.org/10.1016/j.tifs.2014.09.003 Available at https://centaur.reading.ac.uk/43638/

It is advisable to refer to the publisher's version if you intend to cite from the work. See Guidance on citing.

To link to this article DOI: http://dx.doi.org/10.1016/j.tifs.2014.09.003

Publisher: Elsevier

All outputs in CentAUR are protected by Intellectual Property Rights law, including copyright law. Copyright and IPR is retained by the creators or other copyright holders. Terms and conditions for use of this material are defined in the End User Agreement.

www.reading.ac.uk/centaur 
Central Archive at the University of Reading

Reading's research outputs online 
3

4

5

6

8

9

10

11

12

13

14

15

16

17

18

19

20

21 5

Aqueous enzyme assisted oil extraction from oilseeds and emulsion de-emulsifying methods: a review

Masni Mat Yusoff $\underline{\text {, }}^{*}$ Michael H. Gordon, Keshavan Niranjan

Department of Food and Nutritional Sciences, University of Reading, Whiteknights, PO Box 224, Reading, RG6 6AP, United Kingdom

(1)

*Corresponding author:

Tel.: +447450502242

E-mail address: m.matyusoff@pgr.reading.ac.uk

: masniyusoff@upm.edu.my

4 Abstract

5 Regulatory, safety, and environmental issues have prompted the development of aqueous

enzymatic extraction (AEE) for extracting components from oil-bearing materials. The

7 emulsion resulting from AEE requires de-emulsification to separate the oil; when enzymes

are used for this purpose, the method is known as aqueous enzymatic emulsion de-

9 emulsification (AEED). In general, enzyme assisted oil extraction is known to yield oil

having highly favourable characteristics. This review covers technological aspects of

1 enzyme assisted oil extraction, and explores the quality characteristics of the oils obtained, 
22 focusing particularly on recent efforts undertaken to improve process economics by

23 recovering and reusing enzymes.

24

25 Keywords

26 aqueous oil extraction, enzyme treatment, oil yield, oil characteristics, emulsion separation

27

28 1. Introduction

29 Aqueous enzymatic extraction (AEE) is a promising method for the simultaneous

30

31

32

33

34

35

36

37

38

39

40

41

42

43

extraction of oil and protein from oilseeds. The products are of superior quality and highly

suited to human consumption. In the extraction process, water containing selected enzymes

forms the extraction medium used for incubating the oilseeds. When enzymes are not

employed, the process is termed as aqueous extraction which invariably results in lower oil

yield. The use of enzymes allows separation of targeted extracted components with

unchanged properties which can potentially influence, favourably, the final product in

terms of taste and smell. Interest in this technological approach has also increased recently

due to safety and environmental regulatory concerns. In comparison with solvent

extraction, the use of an aqueous medium is much safer, environmental-friendly and

economical. In addition, it contributes to a much safer and flexible operation, lower energy

consumption and operational costs, and lower capital investment. A variety of temporal

crops can be processed, and the extracted oil does not need further refining. Non-toxic meal and value-added fibre and protein are also produced as co-products, due to the milder operating conditions employed. In addition, the aqueous medium allows simultaneous 
44 separation of phospholipids from the oil. Therefore, degumming step (in case of oilseeds)

45 is not necessary and the overall cost of processing can be reduced (Latif \& Anwar, 2011;

46 Latif et al., 2011; Yang Li et al., 2011; Chabrand \& Glatz, 2009; Jung \& Mahfuz, 2009;

47 Wu et al., 2009; Soto et al., 2007; Santos \& Ferrari, 2005; Gros et al., 2003; Hanmoungjai

48 et al., 2001; Rosenthal et al., 2001; Sineiro et al., 1998; Ksenija et al., 1997; Rosenthal et

49 al., 1996)

Despite the advantages, the application of AEE is still limited due to long

51 processing time and the high cost spent for the drying process after the enzyme treatment

52 (Shah et al., 2005; Dominguez et al., 1996). The high cost may also be attributed to the

53 enzymes themselves, because a significant amount is required (normally $>1 \%$ of the weight

54 of the oilseed taken). Further, the non-availability of enzymes on a commercial scale has

55 limited the development of such processes (Rui et al., 2009; Shah et al., 2005). An added

56 problem with AEE is that it is impossible to avoid emulsification of the extracted oil, which

57 requires post extraction de-emulsification to recover and enhance oil yield (Latif \& Anwar,

58 2011; Long et al., 2011; Wu et al., 2009; Chabrand et al., 2008; Santos \& Ferrari, 2005;

59 Rosenthal et al., 1998; Sineiro et al., 1998a). Addition of suitable enzymes to the cream

60 emulsion may be able to separate the oil, and in this paper, this particular sequence of process is

61 termed as aqueous enzymatic emulsion de-emulsification (AEED).

62 In an earlier review by Rosenthal et al. (1996), the principles and mechanisms of:

63 mechanical, solvent, aqueous, and aqueous enzymatic extraction methods have been

64 addressed, besides reviewing the effects of enzymes on plant cell composition and methods

65 employed earlier for de-emulsification. The main purpose of this review is to critically

66 assess the information available to date, in order to conclude whether the enzymatic route 
67 is a viable industrial option for any given oilseed. In addition, the other objectives of this

68 review are: to discuss the effect of incubating conditions in AEE on the oil extraction

69 efficiency; to compare AEE with other extraction methods in terms of yields and

70 characteristics of the oils from various oil-bearing materials; to explore methods available

71 to de-emulsify the oil- aqueous phase emulsions that are inevitably formed during

72 extraction; and finally, to explore the possibility of re-using in the enzyme after recovery in

73 order to make the process more cost effective.

74

75 2. Aqueous enzymatic extraction (AEE) method Table 1 lists the enzymes used in

76 earlier research. In terms of the dispersion structure, Sineiro et al. (1998a) reported that

77 aqueous extraction resulted in oil droplets with spherical shapes in the case of sunflower

78 oil. However, with the use of enzymes, the oil aggregates possessed different shapes with

79 less structured and irregular cell wall surface. Different oils exhibit different properties, and

80 it is reasonable to assume that AEE of different oil-bearing materials result in oil droplets

81 with different characteristics. The enhancement in oil yield with the use of enzymes, i.e.

82 AEE as compared to aqueous extraction without enzymes from various oil-bearing

83 materials are summarized in Table 2. The table also summarizes the differences observed

84 in oil yields between AEE and solvent extraction methods. It is clearly shown that the use

85 of enzymes increases the oil yield, yet it is still lower than the yield when solvent

86 extraction is used. Therefore, numerous studies have been conducted to establish the most

87 suitable enzymes that can be used, either individually or in combination, on various types

88 of oil-bearing materials in order to increase the oil yields. 
90

91

92

93

94

95

96

97

98

99

100

101

102

103

104

105

106

107

108

109

110
2.1. Studies comparing extraction efficiencies using different enzymes

Figure 1(a) and 1(b) illustrate the flow sheets of AEE for soybean and olive oil, respectively. The types of enzymes added depend on the cellular composition and structure of the oil-bearing material (Passos et al., 2009). According to Rosenthal et al. (2001), the use of Alcalase 2.4L (protease) increased the oil yield from heat-treated soybean flour as compared to cellulase, hemicellulase, and pectinase. Similarly, Santos and Ferrari (2005) reported that both Alcalase and Celluclast (cellulase) were able to increase the oil yield from soybeans, with Alcalase giving higher yields. A higher yield in the case of protease (96.0\%) as compared to phospholipase (73.4\%) was also reported by Jung et al. (2009) in the case of extruded soybean flakes. In addition, Lamsal et al. (2006) reported that the use of individual cellulase and a mixture of cellulase and protease did not significantly increase the soybean oil yield from extruded soybean flakes (68\%); yet the yield increased when individual protease was added (88\%). These findings illustrate the specificity of enzymes and enzymatic mixtures for any given oil-bearing material. The presence of protein as a major component in the cell wall of soybean seeds suggests that the oil is released more easily from the cellular matrix by degrading the proteins, which is achieved by the action of protease. In the case of rapeseed, pectin is reported to be the major component of its cell wall (Zhang et al. 2007), hence the highest oil yields, up to $85.9 \%$ in emulsified form, has been reported when pectinase is used which is significantly greater than the values obtained with other carbohydrases. Zhang et al. (2007) also employed a combination of pectinase 
111 with cellulase and $\beta$-glucanase in a ratio of $4: 1: 1$ to result in the highest yield $(91.6 \%$

112 emulsified oil), this marginal enhancement in yield may be attributed to the elimination of

113 other barriers to the release of oil. Similarly, Szydłowska-Czerniak et al. (2010) reported

114 that the application of pectolytic enzyme (ROHAPECT PTE) under optimum conditions

115 prior to pressing produced higher rapeseed free oil yield (16.5\%) as compared to

116 cellulolytic enzyme (15.5\%).

117 Different from oilseeds, addition of enzymes is done on the olive paste in the case of olive 118 fruits, followed by its kneading process as shown in Fig. 1(b). Most studies on extraction of olive 119 oil involved addition of an enzyme mixture consisting mainly pectinase, cellulase, hemicellulase, 120 and other minor enzymes. The studies also reported the inadequacies of these enzymes to extract 121 olive oil if added individually (Aliakbarian et al., 2008; De Faveri et al., 2008; Chiacchierini et 122 al., 2007).

In general, a better oil extraction yield can be expected when a judiciously chosen 124 mixture of enzymes is used because of possible synergy (Passos et al., 2009). However, 125 according to Rovaris et al. (2012), there was no significant difference in soybean oil yields 126 when a mixture of Alcalase $2.4 \mathrm{~L}$ and Viscozyme was used as compared to a mixture of 127 Alcalase $2.4 \mathrm{~L}$ and Celluclast $1.5 \mathrm{~L}(29.48 \%$ as against $26.82 \%$ at $\mathrm{pH} 4.5 ; 20.63 \%$ as 128 against $20.23 \%$ in the case of uncontrolled $\mathrm{pH}$ ), even though Viscozyme itself is a mixture 129 of enzymes. There was also no significant difference in garlic oil yields upon addition of 130 Viscozyme as compared to addition of individual pectinase, protease, and cellulase as 131 reported by Sowbhagya et al. (2009). A similar outcome was reported by Tabtabaei and 132 Diosady (2013) in yellow mustard flour oil extraction when Celluclast 1.5L and Pectinex 133 Ultra SP-L were used, as against Viscozyme L. In addition, the use of Alcalase 2.4L and 
134 Protex 7L resulted in highest sesame (Latif \& Anwar, 2011) and Moringa oleifera (Latif et $135 a l ., 2011)$ seed oils, respectively, in comparison with Viscozyme L, Protex 7L, Natuzyme, 136 Kemzyme, and Multifect CX 13L which are essentially mixtures of enzymes (Latif 137 \&Anwar, 2011; Latif et al., 2011). Viscozyme, being a mixture of enzymes, was reported 138 to have performed better in the case of sunflower oil extraction, which had been proved by 139 Latif and Anwar (2009). A higher oil yield from bush mango kernel flour was also 140 observed upon addition of Viscozyme (68.0\%) as compared to Alcalase (35.0\%) and 141 Pectinex (42.2\%) (Womeni et al., 2008). The different effects of the Viscozyme on oil 142 yields may be due to the nature of different oil-bearing materials and incubating conditions 143 employed.

In a different study conducted by Jiang et al. (2010), five different proteases were 145 tested to improve peanut oil yield, and the highest oil yield was obtained when Alcalase 146 was used (73.45\%), followed by As1398 (66.36\%), Nutrase (60.08\%), Protizyme 147 (55.02\%), and Protamex (48.89\%). A combination of Alcalase with any of these enzymes 148 did not increase the oil yield. Therefore, Jiang et al. (2010) only used Alcalase which 149 reduced the extraction cost, and increased oil yield up to $79.32 \%$ under optimum 150 incubating conditions. Similarly, the use of Neutrase $0.8 \mathrm{~L}$ resulted in marginally lower 151 Moringa oleifera oil yield than when its combination with other three enzymes were 152 employed (Abdulkarim et al., 2006). In the case of flaxseed oil extraction conducted by 153 Long et al. (2011), the addition of cellulase, pectinase, and hemicellulase, individually, 154 gave higher yields than $\beta$-glucosidase and proteinase. Therefore, these authors used a 155 mixture of cellulase, pectinase, and hemicellulase (1:1:1) which resulted in a higher oil 
156 yield of 61.7-66.1\% as compared to the oil yield of each individual enzyme. With reference

157 to Table 2, Zhang et al. (2007) reported highest yield of 92.7\% in the case of rapeseed oil,

158 however, the oil remained very stably emulsified in the cream. Therefore, an alkaline

159 extraction was conducted by using Alcalase which resulted in protein degradation along

160 with an increase in total oil yield.

161 Based on the above studies, it is not possible to establish conclusively whether it is

162 better to use enzymes individually or in combination, although there are numerous

163 instances where there is a possibility that a mixture can work synergistically. The choice of

164 enzyme depends on the location of the oil within the cellular architecture and the

165 biochemical nature of the components surrounding it. It is therefore necessary, not only to

166 look at the dominant biochemical component holding the cellular matrix together, but also

167 investigate the cellular architecture and examine the specific components which act as a

168 barrier against the release of oil. It is only when both these factors are considered

169 simultaneously, the right enzyme mixture can be identified for a given oil-bearing material.

170

171 2.2. Studies on the use of enzyme as a pre-treatment step prior to extraction

172

173 Recently, the application of enzyme pre-treatment prior to oil extraction has been

174 shown to increase yields (Li et al., 2012). The addition of enzymes as a pre-treatment

175 weakens the cells and facilitate the following oil extraction methods such as mechanical

176 pressing and solvent treatment. Furthermore, the advantage of employing this approach lies

177 in the possibility of avoiding the formation of an oil-in-water emulsion that is very difficult 

187 release.

to separate after the extraction processes. The reported enhancement in oil yields with the use of enzyme pre-treatment is summarized in Table 3. In addition to the higher yield, Dominguez et al. (1996) also reported that it was easier to extract the sunflower oil remaining in a mass of pre-treated mechanically pressed cake. In the case of Chilean hazelnuts, enzyme pre-treatment resulted in significantly lower residual oil in the meal as reported by Zuniga et al. (2003). Overall, these studies indicate that enzyme pre-treatment is applicable to various oil-bearing materials and can be employed prior to both mechanical and solvent extraction methods. The oil yield enhancement is due to the hydrolytic action of the enzymes on the cell wall and membrane components which facilitate subsequent oil

\subsection{Studies on pre-treatment step prior to enzymatic extraction}

Some studies have highlighted potential pre-treatment methods, which are not necessarily enzyme-based that could be followed up by AEE as summarized in Table 4. In the case of high pressure processing as reported by Jung and Mahfuz (2009), the use of high pressure induced protein aggregation yet it was further hydrolyzed by protease, thus facilitated oil removal. On the other hand, Shan Liu et al. (2011) reported that ultrasound generated cavitations which accelerated the leaching out of cellular components including oil. The use of extrusion prior to AEE has been extensively studied by Jung and Mahfuz (2009), Jung et al. (2009), and Wu et al. (2009). According to these authors, protein aggregates are formed during extrusion but these entrap or interact with the oil. The 
200

201

202

203

204

205

206

207

208

209

210

211

212

213

214

215

216

217

218

219

220

221

interactions could then be disrupted by the use of protease, which result in increasing the oil and protein yields. These studies have shown the potential of AEE assisted by other pretreatment methods to increase oil yields.

\subsection{Factors affecting the efficiency of enzymatic extraction}

Table 5 summarizes the maximum oil yields resulting from various oil-bearing materials as influenced by the selected and optimized incubating conditions. The key factors affecting the efficiency of AEE will be discussed separately, below.

\subsubsection{Particle size of the oil-bearing materials}

Most of the early studies did not consider the particle size of the oil-bearing material as a key factor influencing extraction efficiency (Passos et al., 2009; Rosenthal et $a l .$, 2001). Theoretically, the lower the particle size, the higher the oil yield for a given set of extraction conditions, which is attributable to higher cell wall disruption during size reduction as well as the lower diffusion path length for both enzymes and cellular components. However, according to Passos et al. (2009), materials with high oil content but exhibiting a weak structure, may collapse and lose their microporosity when treated with solvents, which can result in non-uniform percolation and be detrimental to extraction efficiency. In addition, grinding of materials with high oil content into very low particle sizes may cause the particles to adhere, as reported by Nyam et al. (2009a) in the case of

Kalahari melon seeds. Therefore, in industry, starting materials with very low particle size 
are not recommended and there appears to be an optimum size. This illustrates the importance of selecting the right particle size prior to extraction as had been done by some authors. Sineiro et al. (1998a) used ground soybean and sunflower seeds having mean particle size $<0.2 \mathrm{~mm}$. The grape seeds used by Passos et al. (2009) were grouped into different particle size ranges (in $\mathrm{mm}$ ): $<0.50,0.50-0.60,0.60-0.71,0.71-1.0,1.0-1.4,1.4-$ 2.0, and $>2.0$, and increment in oil yield was observed at lower particle sizes. In the case of linseed oil, Gros et al. (2003) reported no oil recovery from whole linseed kernels, because the substrate was not accessible to the enzymes added. Instead, the hull broke down and the kernels expanded due to hydration. On the other hand, when the kernels were crushed to form different particle sizes including fine powders, the yields improved, particularly after applying hydraulic pressures (Gros et al., 2003). Similarly, in the case of soybean, the use of flour resulted in $24 \%$ higher yield than the flakes (Jung et al., 2009), while $31 \%$ yield enhancement was reported by Rosenthal et al. (1998) when the particle size was reduced from $400 \mu \mathrm{m}$ to $100 \mu \mathrm{m}$.

\subsubsection{Enzyme/substrate ratio}

Higher enzyme concentration leads to greater interaction between the enzyme and substrate, thus promoting cell wall degradation and rupturing more peptide bonds (Teixeira et al., 2013; Jiang et al., 2010; Dominguez et al., 1996). However, too high enzyme concentration may result in bitterness and off flavours, as reported by Jiang et al. (2010), possibly due to the extraction of undesirable components. Most authors have reported similar trends where the oil yield increased up to certain enzyme concentration only, 
244 followed by steady or decreased rate which may be due to saturation of the substrates

245 (Jiang et al., 2010), or caramelization of soluble sugars that limit oil release (Zuniga et al.,

246 2003). In general, the actual concentration used will depend on process economics

247 especially the cost of enzymes (Long et al., 2011; Zhang et al., 2007), and the quality of

248 the oil extracted.

249

250

\subsubsection{Ratio of water to oil-bearing material}

251 The water used in AEE not only serves as an extraction medium but also enters the 252 oil-bearing material and modifies its water activity. The resulting moisture content of the 253 oil-bearing material can assist hydrolytic reaction, diffusion, and mobility of the enzymes 254 and products (Yang Li et al., 2011; Zhang et al. 2007; Sineiro et al., 1998a; Dominguez et $255 a l ., 1996)$. On the other hand, very low moisture content results in the formation of thick 256 suspensions which can prevent the enzymes from effectively penetrating into the substrate 257 (Zhang et al., 2007). Sineiro et al. (1998a) reported that only certain 'areas' in sunflower 258 kernels were degraded by enzymes at low moisture content. Although, materials with 259 higher water activity demonstrate higher extraction efficiency (Soto et al., 2007), the 260 presence of excessive moisture content in the oil-bearing material can decrease the 261 concentration of enzymes and substrates, and have an adverse effect on extraction (Yang Li

262 et al., 2011; Zhang et al., 2007; Dominguez et al., 1996). Therefore, selection of 263 appropriate moisture content is critical for the success of AEE.

264

265

\subsection{4. $p H$ of extraction medium}


267 earlier studies, the $\mathrm{pH}$ value of the solution, be it for soaking pre-treatment or extraction

268 itself, was set at a value corresponding to maximum enzyme activity (Latif \& Anwar, 2011;

269 Jung \& Mahfuz, 2009; Wu et al., 2009; Abdulkarim et al., 2005; Rosenthal et al., 2001;

270 Sineiro et al., 1998). However, the optimum $\mathrm{pH}$ of a number of enzymes is in the range of

271 the isoelectric $\mathrm{pH}$ of proteins which depends on the nature of the oilseeds; since proteins

272 are highly insoluble in this range of $\mathrm{pH}$, oil release may get inhibited. Therefore, the $\mathrm{pH}$

273 value employed must not only be conducive for the action of enzymes but it should also be

274 remote from protein isoelectric point (Tabtabaei \& Diosady, 2013; Wu et al., 2009; Sineiro

275 et al., 1998; Rosenthal et al., 1996). This is yet another reason why many authors

276 considered using a mixture of enzymes which demonstrates high activity at $\mathrm{pH}$ values

277 remote from the isoelectric point and remain effective for oil extraction. The enzymes are

278 able to solubilize and hydrolyze the proteins besides disrupting other polysaccharide

279 constituents which facilitate oil release (Rovaris et al., 2012; Latif \& Anwar, 2011; Passos

280 et al., 2009). Long et al. (2011) had used a mixture of cellulase, pectinase, and

281 hemicellulase (1:1:1) at $\mathrm{pH}$ 4.5-5.0 which resulted in highest flaxseed oil yield (73.9\%) as

282 compared to oil yield of each individual enzyme. In the case of soybean oil, at $\mathrm{pH} 4.5$,

283 Rovaris et al. (2012) used a mixture of Alcalase 2.4L and Celluclast 1.5L which resulted in

$28426.82 \%$ oil $(20.63 \%$ in the case of uncontrolled $\mathrm{pH})$, and a mixture of Alcalase $2.4 \mathrm{~L}$ and

285 Viscozyme which resulted in $29.48 \%$ oil $(20.23 \%$ in the case of uncontrolled $\mathrm{pH})$. A

286 number of studies have also used Protizyme ${ }^{\mathrm{TM}}$ for the AEE (Jiang et al., 2010; Gaur et al.,

287 2010; Sharma et al., 2002). Protizyme ${ }^{\mathrm{TM}}$, being a mixture of proteases, possess different 
288

289

290

291

292

293

294

295

296

297

298

299

300

301

302

303

304

305

306

307

308

309

optimum $\mathrm{pH}$ which allowed selection of any incubating $\mathrm{pH}$ sensitive to the isoelectric point of the major protein fraction of the seeds. Overall, proper $\mathrm{pH}$ selection critically influences yields of oil and other components in AEE.

\subsubsection{Incubation temperature}

Besides being active over a narrow range of $\mathrm{pH}$, enzymes also active over a narrow temperature interval. According to Rui et al. (2009), the optimum temperature range for enzymatic hydrolysis is between $40-55^{\circ} \mathrm{C}$, thus many authors employ AEE temperatures which fall within this range. In practice, one often prefers to use the lowest possible temperature yielding adequate activity (Passos et al., 2009). In the case of olive fruits, a lower temperature of $30^{\circ} \mathrm{C}$ was found to be favourable especially to preserve the oil quality (Aliakbarian et al., 2008; De Faveri et al., 2008; Ranalli et al., 2003; Garcia et al., 2001; Ranalli et al., 1999). Gros et al. (2003) also used a temperature of $34^{\circ} \mathrm{C}$ for similar reason in linseed oil extraction. A significant effect of temperature on oil yield was reported by Sharma et al. (2002), where highest peanut oil yield was observed at $40^{\circ} \mathrm{C}$, but it decreased significantly when the temperature was reduced to $37^{\circ} \mathrm{C}$. According to Zúniga et al. (2003), at temperatures greater than $45^{\circ} \mathrm{C}$, enzymatic hydrolysis begins to decrease due to enzyme inactivation which leads to lower oil yield. The oil release from the cells may also be limited due to presence of soluble sugars in the composition which can undergo caramelization during the drying stage. Therefore, similar trends were reported from most of the conducted studies, where the oil yield increased up to certain temperature only, followed by steady or decreased rate afterwards. Thus, besides the oil yield, the oil 
quality characteristics must also be taken into consideration when selecting AEE

311 temperature.

\subsubsection{Incubation time}

According to Jiang et al. (2010), Abdulkarim et al. (2006), Santos and Ferrari

315 (2005), and Dominguez et al. (1996), degradation of cell wall components can be enhanced

316 by prolonging the incubation time. Passos et al. (2009) also reported that the use of an

317 enzyme mixture of cellulase, protease, xylanase, and pectinase for $120 \mathrm{hr}$ resulted in $3.8 \%$

318 higher yield as compared to $24 \mathrm{hr}$ of incubation time. However, this time duration (i.e. 120

$319 \mathrm{hr}$ ) is far too long to be acceptable in practice (Passos et al., 2009), lower oil quality may

320 result (Jiang et al., 2010), leading to high energy usage and production of undesirable

321 products (Abdulkarim et al., 2006). In addition, Rui et al. (2009) highlighted that longer

322 incubation time of AEE in relation to other solvent extraction methods is one of the

323 disadvantages of AEE. In some cases, the oil yield decreased after a certain incubation

324 period because the whole substrates have reacted with the enzymes; leaving negligible

325 substrates left for further enzymatic reaction to take place (Zhang et al., 2007). On the

326 whole, these studies have shown that although oil yield may increases with time, the rate of

327 increase may be far too slow to warrant extended operations, and the oil quality may also

328 get compromised. 
332 mixing and additional rupture of the cell wall, and agitation rate is one of the factors

333 affecting the disruption of cell wall. Abdulkarim et al. (2006) reported that the agitation

334 rates of 50 and $80 \mathrm{rpm}$ were not adequate to separate the Moringa oleifera oil from other

335 seed components, thus resulted in lower oil yield than at $120 \mathrm{rpm}$. At this agitation rate of

$336120 \mathrm{rpm}$, bigger oil droplets were observed to accumulate at the surface which enabled

337 easier separation. A similar observation was reported at $80 \mathrm{rpm}$ in extraction of peanut oil

338 (Sharma et al., 2002) and at $100 \mathrm{rpm}$ in the extraction of Kalahari melon seed oil (Nyam et

$339 a l ., 2009 \mathrm{a})$. On the other hand, the use of higher speeds leads to higher energy consumption

340 and cost (Rosenthal et al., 1998), besides resulting in the formation of a more stable oil-

341 aqueous phase emulsion that is difficult to separate (Nyam et al., 2009a; Abdulkarim et al.,

342 2006; Sharma et al., 2002, Hanmoungjai et al., 2000). These studies highlight the

343 importance of selecting appropriate agitation rate that will result in the highest oil yield

344 possible, considering both the oil recovered and emulsion stability at the end of the AEE 345 process.

347 2.5. Multi factorial studies on AEE

A number of authors have employed statistical methods to indicate the relative

350 importance of the AEE parameters listed above. According to Rosenthal et al. (2001),

351 soybean oil yield was significantly influenced by the type of enzyme used, the particle size

352 of the ground seeds, the ratio of water to oil-bearing material, and the interaction between 
353 the two latter parameters. However, according to Hanmoungjai et al. (2001), only the

354 enzyme concentration had the most significant effect on the extraction of rice bran oil,

355 while both the incubation time and temperature did not significantly affect the oil yield.

356 Different AEE parameters used for other samples such as bayberry kernels (Zhang et al.,

357 2012), kalahari melon seeds (Nyam et al., 2009a), palm fruit (Teixeira et al., 2013), peanuts

358 (Jiang et al., 2010), and pine kernels (Yang Li et al., 2011) also had different degree of

359 significant effect on oil yield. These studies show that it is almost impossible to generalize

360 which factor is important and which is not, for a given material. It is necessary to undertake

361 an experimental investigation before designing and scaling up an AEE process.

363 3. De-emulsification methods for aqueous enzymatic process (AEED)

364 When oil is extracted into an aqueous enzymatic phase, it inevitably forms an emulsion,

365 which is often difficult to separate because of the added stability imparted by the

366 interfacially active cellular components which are also extracted in the same process. It is

367 therefore necessary to carefully consider the techniques employed to separate the oil,

368 because the final yield and oil quality, and the economic viability of the process, will

369 depend critically on de-emulsification steps. When AEE is followed by a centrifugation

370 step, besides oil, other fractions recovered include a skim and a cream emulsion (Figure

371 1(a)). The cream emulsion is very stable due to its protein content which acts as an

372 excellent emulsifier. Addition of suitable enzymes to the cream emulsion may be able to

373 separate the oil, and in this paper as had been mentioned earlier, this particular sequence of

374 process is termed as aqueous enzymatic emulsion de-emulsification (AEED). The enzymes 
used in the AEED processes were also listed in Table 1. In this method, the enzymes added to the cream emulsion hydrolyze the interfacial proteins, thus reducing their molecular size and decreasing the rigidity of the oil droplet interface. The enzymes also remove the high molecular weight polypeptides which may occupy the emulsion interface and further reduce the interfacial membrane thickness. These enzymatic reactions lead to greater oil droplet coalescence and assist in free oil release (Tabtabaei \& Diosady, 2013; Raghavendra \& Raghavarao, 2010; Chabrand \& Glatz, 2009; Jung \& Mahfuz, 2009; Marina et al., 2009; Wu et al., 2009; Chabrand et al., 2008). The original enzymes used in the AEE may also be carried out into the cream emulsion and assist hydrolytic reactions if suitable incubating conditions were employed (Chabrand \& Glatz, 2009; Jung et al., 2009). The free oil yield is commonly expressed as a percentage based on the initial weight of the cream emulsion. In the case of oil-bearing coconut milk, the emulsion needs to be destabilized in order to obtain virgin coconut oil as shown in Figure 1(c). According to Jena and Das (2006), Garcia et al. (2005), Tangsuphoom and Coupland (2005), and Balasundaresan et al. (2002), coconut milk emulsion is low in stability due to its high fat content and the presence of coconut proteins ( $\sim 65 \%$ is globulin known as cocosin) with low emulsifying properties. Therefore, these authors noted that the separation was not too challenging and concluded that the oil droplets were prone to undergo aggregation and tended to separate. In contrast, Marina et al. (2009), Tangsuphoom and Coupland (2008), Peamprasart and Chiewchan (2006), and McGlone et al. (1986) reported that a coconut cream emulsion was highly stable due to presence of natural phospholipids and coconut proteins (mainly globulins and albumins) which requires extra energy to be destabilized. It is not uncommon 
406 407

to find such conflicting reports in literature, in this area, which is principally because, most papers do not take a holistic view on the whole process. Whether the downstream deemulsification is challenging or not depends on the process conditions employed during AEE. If the conditions employed are such that the emulsion formed is very stable, then the de-emulsification will naturally become challenging. On the other hand, careful process design upstream, and use of conditions that do not favour the formation of a stable emulsion whilst releasing significant yields of oil, will simplify de-emulsification and enhance free oil yields and oil quality.

\subsection{Studies comparing different enzymes for de-emulsification of cream emulsion}

\section{Table 5 summarizes the types of enzymes and the incubating conditions used in} AEED methods for maximum free oil yields. In the case of yellow mustard flour, Tabtabaei and Diosady (2013) reported that Protex 6L possessed greater efficiency in the deemulsification process, as compared to other proteases and carbohydrases tested. Lipomode (Phospholipase A2), being one of the carbohydrases, resulted in the production of lysophospholipids which is an emulsifier, thus increased the emulsion stability and decreased the free oil yield. Lysophospholipids also present in small amount in G-ZYME G999, resulted in an insignificant increase in the free oil yield. In the case of soybean oil, Lamsal and Johnson (2007) concluded that the use of Phospholipase C resulted in higher free oil yield $(73 \pm 5 \%)$ as compared to the mixture of LysoMax ${ }^{\mathrm{TM}}$ and G-ZYME G-999 at 1:1 ratio (68 $\pm 9 \%)$ under the optimum $\mathrm{pH}$ and temperature of the enzymes. Wu et al. (2009) 
419 have also reported that the use of enzymes shown in Table 5 at their optimum $\mathrm{pH}$ and

420

421

422

423

424

425

426

427

428

429

430

431

432

433

434

435

436

437

438

439

440

temperature resulted in total de-emulsification of the cream emulsions, either the enzymes

had been used individually or in combination, or sequentially. These studies indicated that the free oil yield depends on the stability of the cream emulsion which is mainly affected by the AEE, besides the incubating conditions of the AEED which are discussed below.

3.2. Factors affecting the efficiency of enzymatic de-emulsification

\subsubsection{Enzyme concentration}

Generally, the use of higher enzyme concentration resulted in higher free oil yield. According to Jung et al. (2009), at $25^{\circ} \mathrm{C}$, the use of Protex 6L resulted in higher free soybean oil yield of $96 \%$ at $2.5 \%(\mathrm{w} / \mathrm{w})$ concentration when compared to a $85-89 \%$ yield while employing enzyme at $1.25 \%$ (w/w). Similarly, Wu et al. (2009) reported that free soybean oil yield increased with increasing enzyme concentration starting from $0.2 \%$ (w/w). In this study, when the LysoMax ${ }^{\mathrm{TM}}$ enzyme was used at a concentration lower than $0.2 \%(\mathrm{w} / \mathrm{w})$, the enzyme modified soybean phospholipids and caused the production of an emulsifier known as lysolecithin. This emulsifier enhanced the stability of the cream emulsion and therefore resulted in lower free oil yield. In addition, according to Wu et al. (2009), increasing the LysoMax ${ }^{\mathrm{TM}}$ enzyme concentration did not increase the oil droplets size. These authors also reported that in the concentration range of $0.2-2.0 \%(\mathrm{w} / \mathrm{w})$, the use of Protex 51FP resulted in higher free oil yield as compared to the LysoMax $^{\mathrm{TM}}$ which indicated the dominant role of soybean protein in stabilizing the cream emulsion. 
442 3.2.2. $\mathrm{pH}$ value

443 As had been discussed earlier (section 2.4.4), different enzymes possess different 444 optimum $\mathrm{pH}$ where maximum activity is observed. Therefore, most studies employed the 445 optimum $\mathrm{pH}$ of the enzyme used in order to obtain the highest free oil yield (Table 5). In 446 the case of soybean oil, according to Wu et al. (2009), the oil droplet size and free oil yield 447 increased when the $\mathrm{pH}$ was lowered to 4.5 , but not lower than 4.0. At the $\mathrm{pH}$ of 4.5 , which 448 is the isoelectric point of soy protein, electrostatic repulsion between oil droplets decrease, 449 thus further enhancing oil droplets coalescence, formation of larger oil droplets, and higher 450 free oil yield (Wu et al., 2009). In a study conducted by Chabrand and Glatz (2009), the 451 authors reported as high as $83 \%$ free soybean oil yield when the $\mathrm{pH}$ of the cream emulsion 452 was reduced to $\mathrm{pH} 4.5$, and addition of enzyme (G-ZYME G999) at this similar $\mathrm{pH}$ 453 increased the free oil yield up to 100\%. Similarly, Wu et al. (2009) reported that the use of 454 G-ZYME G999 and Protex 50FP separately at pH 4.5 resulted in 100\% free oil yield.

455 These authors suggested that the combination of enzymatic reaction and $\mathrm{pH}$ reduction leads 456 to coalescence of the oil droplets and formation of much bigger droplets than when 457 enzymes are not used. Chabrand and Glatz (2009) had also reported the use of high pH on 458 the free soybean oil yield. At $\mathrm{pH} 9$, only $2 \%$ of free oil yield was recovered. With the use 459 of enzymes (i.e. AEED) at $\mathrm{pH} 8$ which was the original $\mathrm{pH}$ of the cream emulsion, no free 460 oil yield was obtained. Similarly, Wu et al. (2009) reported that the free soybean oil yield 461 decreased when the $\mathrm{pH}$ was increased beyond $\mathrm{pH} 4.5$ up to $\mathrm{pH}$ 8. Therefore, the 462 significance of enzymes addition at suitable $\mathrm{pH}$ values for higher free oil yield is clear. 
464

465

466

467

468

469

470

471

472

473

474

475

476

477

478

479

480

481

482

483

484

\subsubsection{Incubation time and temperature}

Similar to the $\mathrm{pH}$ value, different enzymes possess different optimum temperature where maximum activity is observed. Therefore, most earlier studies employed the optimum temperature reported for the enzyme used in order to obtain highest free oil yield (Table 5). Jung et al. (2009)reported the effect of different de-emulsification temperatures and times on the free soybean oil yield when Protex 6L was used. Prolonged incubation time from 2 min to 90 min enhanced the free oil yield from $86 \%$ to $100 \%$ at $65{ }^{\circ} \mathrm{C}$.

However, the incubation time did not affect the free oil yield at lower temperatures of 25 ${ }^{\circ} \mathrm{C}$ and $50{ }^{\circ} \mathrm{C}$. Increment of temperature from $50{ }^{\circ} \mathrm{C}$ to $65^{\circ} \mathrm{C}$ also increased the free oil yield from $90 \%$ to $100 \%$ after incubation for $90 \mathrm{~min}$. In the case of coconut milk deemulsification, Raghavendra and Raghavarao (2010) reported a higher free oil yield when the use of enzyme was followed by chilling and thawing. In this case, a higher free oil yield of $94.5 \%$ was reported at a higher temperature of $37{ }^{\circ} \mathrm{C}$ as compared to $91.0 \%$ yield at 25

${ }^{\circ} \mathrm{C}$, because according to these authors, most enzymes possess an optimum temperature of $37^{\circ} \mathrm{C}$. In addition, chilling resulted in packed oil bodies which are easier to separate (Raghavendra \& Raghavarao, 2010).

It is also possible to demulsify without the use of enzymes as reported by Jung et al. (2009). In this study, the increase in temperature from $50{ }^{\circ} \mathrm{C}$ to $65^{\circ} \mathrm{C}$ increased the free oil yield from $75 \%$ to $94 \%$. According to the authors, the significant increase in free oil yield may be due to the action of remaining protease in the cream emulsion which was carried out from the AEE. In the case of yellow mustard flour, Tabtabaei and Diosady (2013) 
485 subjected the emulsion recovered after AEED process to an alkaline treatment which 486 resulted in higher oil yield than AEED alone.

487 Other processing parameters such as shaking, de-canting, and stirring may also 488 influence de-emulsification efficiency (Jung et al., 2009).

\section{Oil characteristics}

491 Most authors have reported the effects of extraction methods on the oil characteristics 492 which are summarized in Table 6. With reference to the table, the oil yields from most of 493 the enzyme treatments were lower in oxidative deterioration and rancidity, indicated by the

494 lower free fatty acids and peroxide values as compared to the yields from solvent 495 treatments. It was assumed that the high temperature used during the solvent extraction 496 resulted in lower oxidative quality of the oils (Latif et al., 2011; Latif \& Anwar, 2011; Latif 497 \& Anwar, 2009; Latif et al., 2008). The peroxide value of rice bran oil extracted by solvent 498 was also higher than that extracted enzymatically, but the difference was too small to the 499 limit industrial application (Hanmoungjai et al., 2001). In contrast, Kalahari melon seed oil 500 from AEE process gave higher free fatty acid and peroxide value than solvent extracted oil.

501 This may be due to the lipase activity in the seeds during the initial heating in the case of 502 AEE process (Nyam et al., 2009).

503 With reference to Table 6, some of the enzymatically extracted oils gave higher 504 iodine value (IV) than aqueous and solvent extracted oils. Hanmoungjai et al. (2001) and 505 Long et al. (2011) reported that the higher IV indicated higher polyunsaturated fatty acid 506 content which therefore suggested a higher antioxidant activity. In addition, highest total 
tocopherols was observed in most seed oils obtained from the AEE, followed by aqueous and solvent extracted oils. It was suggested that the higher temperature employed in the solvent treatment reduced the tocopherol content in the oil (Latif et al., 2011; Latif \& Anwar, 2011). The total tocopherols in olive oils reported by Ranalli et al. (2001) and Ranalli et al. (2003) were also higher when AEE was employed as compared to aqueous extractions without enzymes. In contrast, Nyam et al. (2009) reported lower total tocopherol content in the Kalahari melon oil obtained by AEE than solvent extraction method. This may be due to the production of components during the digestion process in the AEE that can influence the amount of non-saponifiable matter, including tocopherols (Gunstone, 2000), In terms of total phenolic content, the values varied with different oil-bearing materials, extraction methods employed, and the types of enzymes used in the AEE process. In the case of olive oil, AEE resulted in higher total phenolic content than the aqueous extractions without enzymes. This may be due to cell wall hydrolysis by the enzymes used which further assists partitioning of the phenolics into the oil. The phenolic content positively influences oxidative stability, shelf life, nutritional, sensory, and health properties of the olive oil, besides flavour which got a greater sensory score (Latif \& Anwar, 2009, 2011; Aliakbarian et al., 2008; Ranalli et al., 2003; Ranalli et al., 1999; Ranalli \& De Mattia, 1997). Najafian et al. (2009) also reported that at higher enzyme concentration, the phenolic content increased whilst the oil turbidity decreased, which may be due to the enzymatic effect in reducing the amount of colloidal particles. 
In terms of the fatty acid compositions (FAC), most authors reported similarities

529 between the oils obtained from solvent and enzymatic extraction methods (Teixeira et al.,

530 2013; Li et al., 2012; Zhang et al., 2012; Latif et al., 2011; Latif \& Anwar, 2009, 2011;

531 Jung et al., 2009; Nyam et al., 2009, 2009a; Latif et al., 2008). In a study conducted by Rui

532 et al. (2009), the FAC of the pitaya oil obtained from microwave-pre-treated enzyme

533 treatment was similar to the recommended FAC by the US dietary standard. Rui et al.

534 (2009) suggested that microwave irradiation enhanced volumetric swelling of the cells in

535 the seed kernels which caused cell walls rupture, while the enzymes hydrolyzed the cell

536 wall and the bonds between the protein or pectin. A combination of these methods led to

537 extraction of pitaya oil with varying fatty acid types as compared to other methods. In the

538 case of flaxseed oil, Long et al. (2011) reported that the oil yield from enzyme-pre-treated

539 ultrasonication possessed higher monounsaturated and polyunsaturated fatty acids than the

540 flaxseed oil obtained by solvent extraction. According to the authors, the use of water

541 allowed diffusion of water-soluble components instead of the oil. Therefore, the oil

542 possessed approximately similar FAC as the original flaxseed oil (Long et al., 2011).

543 In addition to the characteristics listed in Table 6, the colour intensity of oil had also

544 been reported in some studies based on red and yellow units; higher values of these units

545 correspond to higher colour intensity. In the case of Moringa oleifera seeds, according to

546 Latif et al. (2011) and Abdulkarim et al. (2006), the different enzymes used in the AEE

547 processes act on different components of the seeds which resulted in oil yields having

548 different colour intensity. However, the difference was more significant between the oil

549 obtained by AEE and solvent extraction methods, which is similar to the results reported by 
550 Nyam et al. (2009) and Latif et al. (2008) for Kalahari melon and canola seed oil,

551 respectively. The solvent-extracted oil had higher colour intensity which may due to the

552 pigments extracted by the solvent into the oil, such as carotenes and chlorophylls. The oil

553 obtained from AEE process may not need refining due to low colour intensity which

554 reduces the processing costs (Latif \& Anwar, 2009; Nyam et al., 2009; Latif et al., 2008;

555 Abdulkarim et al., 2006, Abdulkarim et al., 2005).

556 Besides the colour of the oils, the sterols were also significantly lower in oil

557 obtained by AEE than solvent extracted oil, which suggests the ability of the solvent used

558 to extract lipid-soluble components (Nyam et al., 2009). In addition to these characteristics,

559 Sowbhagya et al. (2009) reported that the use of enzymes as a pre-treatment prior to steam

560 distillation or hydrodistillation resulted in garlic oil with higher concentration of dithiins

561 which possess health benefits and highly desirable from a nutraceutical point of view. In

562 the case of soybean oil, with the use of enzymes, Jung et al. (2009) reported lower

563 phosphorus content $(<200 \mathrm{ppm})$ which comply with the specification of the National

564 Oilseed Processors Association trading rules for crude degummed soybean oil. In a study

565 done by Ranalli et al. (1999), the Cytolase 0 enzyme used in olive oil extraction was

566 harmless and water-soluble. Therefore, after the enzyme exerted all its effects on oil

567 extraction, it came out into the water (i.e. olive juice) and left no residue in the oil. Thus the

568 olive oil composition was not modified.

569 In extraction of virgin coconut oil from coconut milk emulsion, a combination of

570 AEED, chilling, and thawing for the coconut milk destabilization resulted in highest

571 creaming index as compared to other destabilization methods which indicated faster oil 
572 droplets movement and higher droplets aggregation. As compared to commercial coconut 573 oil sample, the coconut oil possessed higher caprylic (9.4\%), capric (6.3\%), and medium 574 chain (69.7\%) fatty acids. These fatty acid types are known to impart health benefits, and 575 contribute to higher oxidative stability to the oil itself. In addition, the resulting coconut oil 576 was also lower in acid value $(0.27 \%)$ which also corresponds to lower free fatty acids, as 577 compared to the commercial coconut oil $(0.91 \%)$. The free fatty acids are responsible for 578 undesirable flavour in the oil. Therefore overall, the coconut oil obtained from AEED 579 followed by chilling and thawing seems to possess greater oxidative stability, and the 580 attributes measured were within the Asian and Pacific Coconut Community standards 581 (Raghavendra \& Raghavarao, 2010). Overall, enzyme based extraction methods result in oils with better characteristics 583 as compared to oil obtained from solvent and aqueous extraction methods. Therefore, 584 further studies are desirable to enable industrial application by scaling up.

\section{Potentials for re-using enzymes in enzymatic extraction methods}

587 Rosenthal et al. (1996) highlighted the possible alternatives for improvement of aqueous 588 extraction, including the use of enzymes (i.e. AEE), the optimization of both extraction and 589 de-emulsification processes, utilization of membrane technology, and the potential of water 590 recycling (i.e. enzyme recycling in the case of AEE). Enzyme recycling may assist in

591 reducing the cost of $\mathrm{AEE}$ which bears the potential to compete with conventional 592 extraction method based on the market price commanded by the oil (Nyam et al., 2009a) 
594 soybean oil, the aqueous phase recovered contained $84.7 \%$ of the remaining Protex 6L 595 activity. After separation, a major part of this enzyme activity was recovered in the skim 596 fraction (Jung et al., 2009). Similarly, 100\% of Protex 6L activity remained in the skim 597 fraction in a study conducted by Chabrand and Glatz (2009). These findings indicate the 598 possibility of recovering and re-using the skim fraction as a source of water and enzyme at 599 the upstream end of the process (Jung et al., 2009). In addition, Jung et al. (2009) reported 600 lower Protex 6L activity in the cream emulsion, yet adequate to increase the free oil yield 601 with the use of suitable incubation time and temperature. Droplet coalescence was also 602 promoted by the gentle stirring during the incubation of the cream emulsion (Jung et al., 603 2009).

604 Studies concerning the enzyme recycling were conducted in order to improve 605 process economics and lower the environmental impact of the process. Another method 606 which has gained recent interests is the enzyme immobilization, where the enzymes are 607 separated from the treated products before being re-used. It was reported that the separated 608 enzymes possessed enhanced stability (Long et al., 2011; Wan et al., 2008; Roy et al., 609 2004). The increasing demands on enzyme-based methods have resulted in production of 610 more enzymes at lower production costs (Roy et al., 2004; Mondal et al., 2003; Sharma et 611 al., 2003; Chase, 1994).

\section{Concluding remarks}


614 This review has highlighted the main process, advantages, and disadvantages of AEE and 615 AEED as alternative methods for conventional solvent based extraction methods. In order

616 to enhance the oil yield, a combination of AEE with other non-enzymatic processing 617 methods prior to, or after AEE, has been widely conducted and relevant studies have been 618 reviewed in this paper. The process factors influencing AEE and AEED efficiencies, as

619 well as the oil characteristics, have also been discussed. On the whole, the process factors 620 are correlated with each other, and statistical optimization is currently the best solution for 621 investigating the interacting effects between the contributing factors for obtaining highest 622 oil yield with favourable quality. The high cost of enzymes and production of lower oil 623 yield than that of solvent extraction method have been the major drawbacks of AEE 624 process. Despite the problems, the interest in this method for oil and protein extraction has 625 progressively increased due to the perceived environmental advantages.

626

\section{Acknowledgements}

628 The authors gratefully acknowledge the Ministry of Higher Education (MOHE) Malaysia 629 for supporting the doctoral grant, and to the Universiti Putra Malaysia, UPM Serdang, 630 Malaysia for giving permission to one of the authors (Masni Mat Yusoff) to study in the 631 University of Reading, Reading, UK.

\section{References}

634 Abdulkarim, S. M., Long, K., Lai, O. M., Muhammad, S. K. S., Ghazali H. M. (2005). 635 and aqueous enzymatic methods. Food Chemistry, 93, 253-263. 
653

654Chabrand, R. M., Kim, H. -J., Zhang, C., Glatz, C. E., Jung, S. (2008). Destabilization of 655 emulsion formed during aqueous extraction of soybean oil. Journal of the American Oil 656 Chemists' Society, 85, 383-390.

657

658

659

660

661

662

663

664

665

666

667

668

669

670

671

672

673

674

675

676

677

678

679

Abdulkarim, S. M., Lai, O. M., Muhammad, S. K. S., Long, K., Ghazali, H. M. (2006). Use of enzymes to enhance oil recovery during aqueous extraction of Moringa oleifera seed oil. Journal of Food Lipids, 13, 113-130.

Aliakbarian, B., Faveri, D. D., Converti, A., Perego, P. (2008). Optimisation of olive oil extraction by means of enzyme processing aids using response surface methodology. Biochemical Engineering Journal, 42, 34-40.

Balasundaresan, D., Sugadev, R., Ponnuswamy, M. N. (2002). Purification and crystallization of coconut globulin cocosin from Cocos nucifera. Biochemica et Biophysica Acta, 1601, 121-122.

Chabrand, R. M., Glatz, C. E. (2009). Destabilization of the emulsion formed during the enzyme-assisted aqueous extraction of oil from soybean flour. Enzyme and Microbial Technology, 45, 28-35.

Chase, H. A. (1994). Purification of protein by adsorption chromatography in expanded beds. Trends in Biotechnology, 12, 294-303.

Chiacchierini, E., Mele, G., Restuccia, D., Vinci, G. (2007). Impact evaluation of innovative and sustainable extraction technologies on olive oil quality. Trends in Food Science and Technology, 18, 299-305.

de Moura, J. M. L. N., Mahfuz, A., Campbell, K., Jung, S., Glatz, C. E., Johnson, L. A. (2008). Enzymatic aqueous extraction of soybean oil and protein and cream deemulsification. Journal of the American Oil Chemists' Society, 85, 985-995.

Dominguez, H., Sineiro, J., Núnez, M. J., Lema, J. M. (1996). Enzymatic treatment of sunflower kernels before oil extraction. Food Research International, 28, 537-545.

De Faveri, D., Aliakbarian, B., Avogadro, M., Perego, P., Converti, A. (2008). Improvement of olive oil phenolics content by means of enzyme formulations: Effect of different enzyme activities and levels. Biochemical Engineering Journal, 41, 149-156.

Gai, Q. Y., Jiao, J., Mu, P. S., Wang, W., Luo, M., Li, C. Y., Zu, Y. G., Wei, F. Y., Fu, Y. J. (2013). Microwave-assisted aqueous enzymatic extraction of oil from Isatis indigotica seeds and its evaluation of physicochemical properties, fatty acid compositions and antioxidant activities. Industrial Crops and Products, 45, 303-311. 
680

681

682

683

684

685

686

687

688

689

690

691

692

693

694

695

696

697

698

699

700

701

702

703

704

705

706

707

708

709

710

711

712

713

714

715

716

717

718

719

720

721

722

723

García, A., Brenes, M., Moyano, M. J., Alba, J., García, P., Garrido, A. (2001). Improvement of phenolic compound content in virgin olive oils by using enzymes during malaxation. Journal of Food Engineering, 48, 189-194.

Garcia, R. N., Arocena, R. V., Laurena, A. C., Tecson-Mendoza, E. M. (2005). 11S and 7S globulins of coconut (Cocos nucifera L.): purification and characterization. Journal of Agricultural and Food Chemistry, 53(5), 1734-1739.

Gaur, R., Sharma, A., Khare, S. K., Gupta, M. N. (2007). A novel process for extraction of edible oils Enzyme assisted three phase partitioning (EATPP). Bioresource Technology, 98, 696-699.

Gros, C., Lanoisellé, J. -L., Vorobiev, E. (2003). Towards an alternative extraction process for linseed oil. Trans IChemE, 81, 1059-1065.

Gunstone, F. D. (2000). Composition and properties of edible oils. In W. Hamm, \& R. J. Hamilton (Eds.), Edible oil processing (pp. 1-33). Sheffield, UK: Sheffield Academic Press.

Hanmoungjai, P., Pyle, D. L., Niranjan, K. (2000). Extraction of rice bran oil using aqueous media. Journal of Chemical Technology and Biotechnology, 75, 348-352.

Hanmoungjai, P., Pyle, D. L., Niranjan, K. (2001). Enzymatic process for extracting oil and protein from rice bran. Journal of the American Oil Chemists' Society, 78, 817-821.

Hu, W., Zou, Y. (2013). Optimization of enzyme-assisted extraction processing of oil from pumpkin seed by response surface methodology. Science and Technology of Food Industry, 34(3), 277-280.

Jena, S., Das, H. (2006). Modeling of particle size distribution of sonicated coconut milk emulsion: Effect of emulsifiers and sonication time. Food Research International, 39, 606-611.

Jiang, L., Hua, D., Wang, Z., Xu, S. (2010). Aqueous enzymatic extraction of peanut oil and protein hydrolysates. Foods and Bioproducts Processing, 88, 233-238.

Jung, S., Mahfuz, A. A. (2009). Low temperature dry extrusion and high-pressure processing prior to enzyme-assisted aqueous extraction of full fat soybean flakes. Food Chemistry, 114, 947-954.

Jung, S., Maurer, D., Johnson, L. A. (2009). Factors affecting emulsion stability and quality of oil recovered from enzyme-assisted aqueous extraction of soybeans. Bioresource Technology, 100, 5340-5347. 
760

Ksenija, P. J., Zarko, V., Miyjana, M. (1997). Aqueous-enzymatic extraction of plum kernel oil. Fett-Lipid, 99, 433-435.

Lamsal, B. P., Johnson, L. A. (2007). Separating oil from aqueous extraction fractions of soybean. Journal of the American Oil Chemists' Society, 84, 785-792.

Lamsal, B. P., Murphy, P. A., Johnson, L. A. (2006). Flaking and extrusion as mechanical treatments for enzyme-assisted aqueous extraction of oil from soybeans. Journal of the American Oil Chemists' Society, 83(11), 973-979.

Latif, S., Diosady, L. L., Anwar, F. (2008). Enzyme-assisted aqueous extraction of oil and protein from canola (Brassica napus L.) seeds. European Journal of Lipid Science and Technology, 110, 887-892.

Latif, S., Anwar, F. (2009). Effect of aqueous enzymatic processes on sunflower oil quality. Journal of the American Oil Chemists' Society, 73, 1663-1667.

Latif, S., Anwar, F. (2011). Aqueous enzymatic sesame oil and protein extraction. Food Chemistry, 125, 679-684.

Latif, S., Anwar, F., Hussain, A. I., Shahid, M. (2011). Aqueous enzymatic process for oil and protein extraction from Moringa oleifera seed. European Journal of Lipid Science and Technology, 113, 1012-1018.

Li, F., Yang, L., Zhao, T., Zhao, J., Zou, Y., Zou, Y., Wu, X. (2012). Optimization of enzymatic pretreatment for n-hexane extraction of oil from Silybum marianum seeds using response surface methodology. Food and Bioproducts Processing, 90, 87-94.

Li, J., Zu, Y. G., Luo, M., Gu, C. B., Zhao, C. J., Efferth, T., Fu, Y. J. (2013). Aqueous enzymatic process assisted by microwave extraction of oil from yellow horn (Xanthoceras sorbifolia Bunge.) seed kernels and its quality evaluation. Food Chemistry, 138, 2152-2158.

Long, J. J., Fu, Y. J., Zu, Y. G., Li, J., Wang, W., Gu, C. B., Luo, M. (2011). Ultrasoundassisted extraction of flaxseed oil using immobilized enzymes. Bioresource Technology, 102, 9991-9996.

Marina, A. M., Che Man, Y. B., Amin, I. (2009). Virgin coconut oil: emerging functional food oil. Trends in Food Science and Technology, 20, 481-487

McGlone, O. C., Canales, A. L. M., Carter, J. V. (1986). Coconut oil extraction by a new enzymatic process. Journal of Food Science, 51(3), 695-697 
808

809

810
Mondal, K., Mehta, P., Gupta, M. N. (2003). Affinity precipitation of Aspergillus niger pectinase by microwave treated alginate. Protein Expression and Purification, 33, 104109.

Najafian, L., Ghodsvali, A., Haddad Khodaparast, M. H., Diosady, L. L. (2009). Aqueous extraction of virgin olive oil using industrial enzymes. Food Research International, $42,171-175$.

Nyam, K. L., Tan, C. P., Che Man, Y. B., Lai, O. M., Long, K. (2009). Physicochemical properties of Kalahari melon seed oil following extractions using solvent and aqueous enzymatic methods. International Journal of Food Science and Technology, 44, 694701.

Nyam, K. L., Tan, C. P., Lai, O. M., Long, K., Che Man, Y. B. (2009a). Enzyme-assisted aqueous extraction of Kalahari melon seed oil: optimization using response surface methodology. Journal of the American Oil Chemists' Society, 86(12), 1235-1240.

Passos, C. P., Yilmaz, S., Silva, C. M., Coimbra, M. A. (2009). Enhancement of grape seed oil extraction using a cell wall degrading enzyme cocktail. Food Chemistry, 115, 48-53.

Peamprasart, T., Chiewchan, N. (2006). Effect of fat content and preheat treatment on the apparent viscosity of coconut milk after homogenization. Journal of Food Engineering, 77, 653-658.

Raghavendra, S. N., Raghavarao, K. S. M. S. (2010). Effect of different treatments for the destabilization of coconut milk emulsion. Journal of Food Engineering, 97, 341-347.

Ranalli, A., De Mattia, G. (1997). Characterisation of olive oil produced with a new enzyme processing aid. Journal of the American Oil Chemists' Society, 74, 1105-1113.

Ranalli, A., Malfatti, A., Cabras, P. (2001). Composition and quality of pressed virgin olive oils extracted with a new enzyme processing aid. Journal of Food Science, 66, 592603.

Ranalli, A., Malfatti, A., Pollastri, L., Contento, S., Lucera, L. (2003). Analytical quality and genuineness of enzyme-extracted virgin olive oil. Journal of Food Quality, 26, 149-164.

Ranalli, A., Sgaramella, A., Surricchio, G. (1999). The new "Cytolase 0" enzyme processing aid improves quality and yields of virgin olive oil. Food Chemistry, 66, 443454.

Rosenthal, A., Pyle, D. L., Niranjan, K. (1996). Aqueous and enzymatic processes for edible oil extraction. Enzyme and Microbial Technology, 19, 402-420. 
811

812

813

814

815

816

817

818

819

820

821

822

823

824

825

826

827

828

829

830

831

832

833

834

835

836

837

838

839

840

841

842

843

844

845

846

847

848

849

850

851

852

853

854

Rosenthal, A., Pyle, D. L., Niranjan, K. (1998). Simultaneous aqueous extraction of oil and protein from soybean: mechanisms for process design. Trans IChemE., 76, 224-230.

Rosenthal, A., Pyle, D. L., Niranjan, K., Gilmour, S., Trinca, L. (2001). Combined effect of operational variables and enzyme activity on aqueous enzymatic extraction of oil and protein from soybean. Enzyme and Microbial Technology, 28, 499-509.

Rovaris, A. A., Dias, C. O., da Cunha, I. P., Scaff, R. M. C., de Francisco, A., Petkowicz, C. L. O., Amante, E. R. (2012). Chemical composition of solid waste and effect of enzymatic oil extraction on the microstructure of soybean (Glycine max). Industrial Crops and Products, 36, 405-414.

Roy, I., Sharma, S., Gupta, M. N. (2004). Smart biocatalysts: design and applications. In T. Scheper (Ed.), Biochemical Engineering and Biotechnology (pp. 159-189). Berlin: Springer-Verlag.

Rui, H., Zhang, L., Li, Z., Pan, Y. (2009). Extraction and characteristics of seed kernel oil from white pitaya. Journal of Food Engineering, 93, 482-486.

Santos, R. D., Ferrari, R. A. (2005). Extração aquosa enzimática de óleo de soja. Ciênc. Technologia Alimentaria, 25(1), 132-138.

Shah, S., Sharma, A., Gupta, M. N. (2005). Extraction of oil from Jatropha curcas L. seed kernels by combination of ultrasonication and aqueous enzymatic oil extraction. Bioresource Technology, 96, 121-123.

Shan Liu, Jiang, L., Li, Y. (2011). Research of aqueous enzymatic extraction of watermelon seed oil of ultrasonic pretreatment assisted. Procedia Engineering, 15, 4949-4955.

Sharma, A., Khare, S. K., Gupta, M. N. (2002). Enzyme-assisted aqueous extraction of peanut oil. Journal of the American Oil Chemists' Society, 79(3), 215-218.

Sharma, A., Mondal, K., Gupta, M. N. (2003). Separation of enzymes by sequential macroaffinity ligand-facilitated three-phase partitioning. Journal of Chromatography A, 995, 127-134.

Sineiro, J., Dominguez, H., Núnez, M. J., Lema, J. M. (1998). Optimization of the enzymatic treatment during aqueous oil extraction from sunflower seeds. Food Chemistry, 61, 467-474.

Sineiro, J., Dominguez, H., Nunez, M. J., Lema, J. M. (1998a). Microstructural features of enzymatically treated oilseeds. Journal of the Science of Food and Agriculture, 78(4), 491-497. 
855

856

857

858

859

860

861

862

863

864

865

866

867

868

869

870

871

872

873

874

875

876

877

878

879

880

881

882

883

884

885

886

887

888

889

890

891

892

893

894

895

896

897

898

Soto, C., Chamy, R., Zúniga, M. E. (2007). Enzymatic hydrolysis and pressing conditions effect on borage oil extraction by cold pressing. Food Chemistry, 102, 834-840.

Sowbhagya, H. B., Purnima, K. T., Florence, S. P., Appu Rao, A. G., Srinivas, P. (2009). Evaluation of enzyme-assisted extraction on quality of garlic volatile oil. Food Chemistry, 113, 1234-1238.

Szydłowska-Czerniak, A., Karlovits, G., Hellner, G., Szłyk, E. (2010). Effect of enzymatic and hydrothermal treatments of rapeseeds on quality of the pressed rapeseed oils: part II. Oil yield and oxidative stability. Process Biochemistry, 45, 247-258.

Tabtabaei, S., Diosady, L. L. (2013). Aqueous and enzymatic processes for the production of food-grade proteins and industrial oil from dehulled yellow mustard flour. Food Research International, 52, 547-556.

Tangsuphoom, N., Coupland, J. N. (2005). Effect of heating and homogenization on the stability of coconut milk emulsions. Journal of Food Science, 70(8), E466-E470.

Tangsuphoom, N., Coupland, J. N. (2008). Effect of surface-active stabilizers on the microstructure and stability of coconut milk emulsions. Food Hydrocolloids, 22, 12331242.

Teixeira, C. B., Macedo, G. A., Macedo, J. A., da Silva, L. H. M., Rodrigues, A. M. C. (2013). Simultaneous extraction of oil and antioxidant compounds from oil palm fruit (Elaeis guineensis) by an aqueous enzymatic process. Bioresource Technology, 129, 575-581.

Wan, L. S., Ke, B. B., Xu, Z. K. (2008). Electrospun nanofibrous membranes filled with carbon nanotubes for redox enzyme immobilization. Enzyme and Microbial Technology, 42, 332-339.

Womeni, H. M., Ndjouenkeu, R., Kapseu, C., Mbiapo, F. T., Parmentier, M., Fanni, J. (2008) Aqueous enzymatic oil extraction from Irvingia gabonensis seed kernels. European Journal of Lipid Science and Technology, 110, 232-238.

Wu, J., Johnson, L. A., Jung, S. (2009). Demulsification of oil-rich emulsion from enzymeassisted aqueous extraction of extruded soybean flakes. Bioresource Technology, 100, 527-533.

Xiaonan Sui, Jiang, L., Li, Y., Liu, S. (2011). The research on extracting oil from watermelon seeds by aqueous enzymatic extraction method. Procedia Engineering, 15, 4673-4680. 
902

903

904

905

906

907

908

909

910

911

912

913

914

915

916

917

918

919

920

921

922

923

924

925

926

927

928

929

930

Yang Li, Jiang, L., Sui, X., Wang, S. (2011). Optimization of the aqueous enzymatic extraction of pie kernel oil by response surface methodology. Procedia Engineering, $15,4641-4652$.

Zhang, S. B., Wang, Z., Xu, S. Y. (2007). Optimization of the aqueous enzymatic extraction of rapeseed oil and protein hydrolysates. Journal of the American Oil Chemists' Society, 84, 97-105.

Zhang, Y. L., Li, S., Yin, C. P., Jiang, D. H., Yan, F. F., Xu, T. (2012). Response surface optimisation of aqueous enzymatic oil extraction from bayberry (Myrica rubra) kernels. Food Chemistry, 135, 304-308.

Zhang, Y., Li, Y., Jiang, L. Z., Wang, Y., Zhang, Y., Feng, H., Sui, X. (2013). Research of hydrolysis de-emulsification of emulsion from enzyme-assisted aqueous extraction processing of Perilla frutescens. Science and Technology of Food Industry, 34(4), 201206,211 .

Zúniga, M. E., Soto, C., Mora, A., Chamy, R., Lema, J. M. (2003). Enzymic pre-treatment of Guevina avellana mol oil extraction by pressing. Process Biochemistry, 39, 51-57.

Figure caption

Fig. 1. Flow sheet for (a) production of extruded soybean oil by aqueous enzymatic extraction and free soybean oil recovery by aqueous enzymatic emulsion de-emulsification method (Adapted from Lamsal and Johnson, 2007; Jung et al., 2009; Wu et al., 2009; Chabrand and Glatz, 2009); (b) production of olive oil by aqueous enzymatic extraction with different post-treatments (Adapted from Ranalli et al., 1999; Garcia et al., 2001; Ranalli et al., 2001; Ranalli et al., 2003; De Faveri et al., 2008; Najafian et al., 2009); and (c) production of virgin coconut oil by aqueous enzymatic emulsion de-emulsification method (Adapted from Raghavendra and Raghavarao, 2010).

\section{Table captions}


932 Table 1. Commercial enzymes used for aqueous enzymatic extraction (AEE) and 933 aqueous enzymatic emulsion de-emulsification (AEED) processes: descriptions and 934 compositions.

935 Table 2. The oil yield enhancement with the use of enzymes, and the oil yield

936 difference between the enzyme and solvent extraction methods.

937 Table 3. Enhancement in oil yield due to presence of enzyme pre-treatment prior to

938 the extraction method, as compared to the extraction method alone.

939 Table 4. The advantages of the use of pre-treatments (non-enzymatic) prior to the 940 enzymatic extraction method.

941 Table 5. Maximum oil yields as affected by the selected and optimized incubating

942 conditions of the aqueous enzymatic extraction and aqueous enzymatic emulsion de-

943 emulsification methods.

944 Table 6. The characteristics of oil yields from solvent, aqueous, and aqueous

945 enzymatic extraction methods.

946 


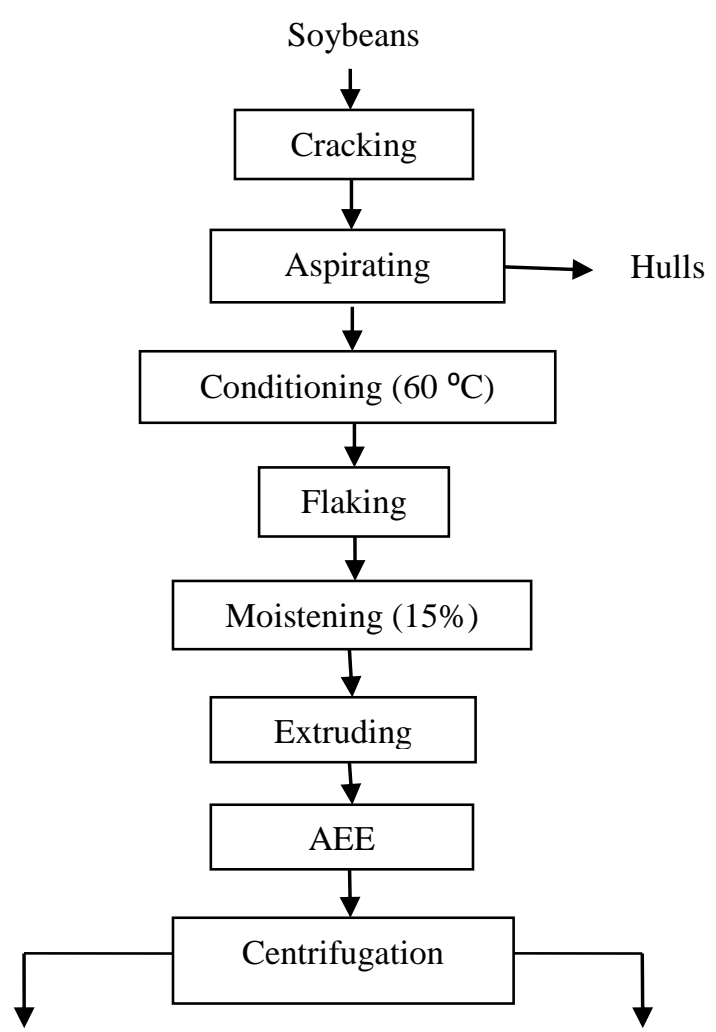

13

14

15

16

17

18

Insoluble / Precipitate

/ Solid residue (Fiber)

Liquid fraction / Aqueous phase

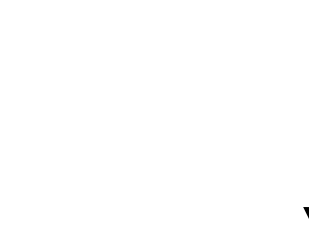

Separatory funnel /

Separation methods

19

20

21

22

Cream emulsion

(Proteins, sugars, oil)

Extracted

$($ Cream + free oil $)$

soybean oil

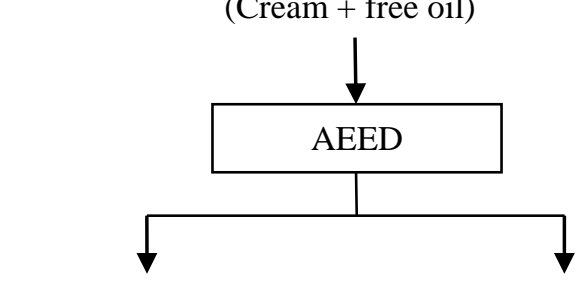

Free soybean oil

Second skim

23

24

25

(a)

26

27 


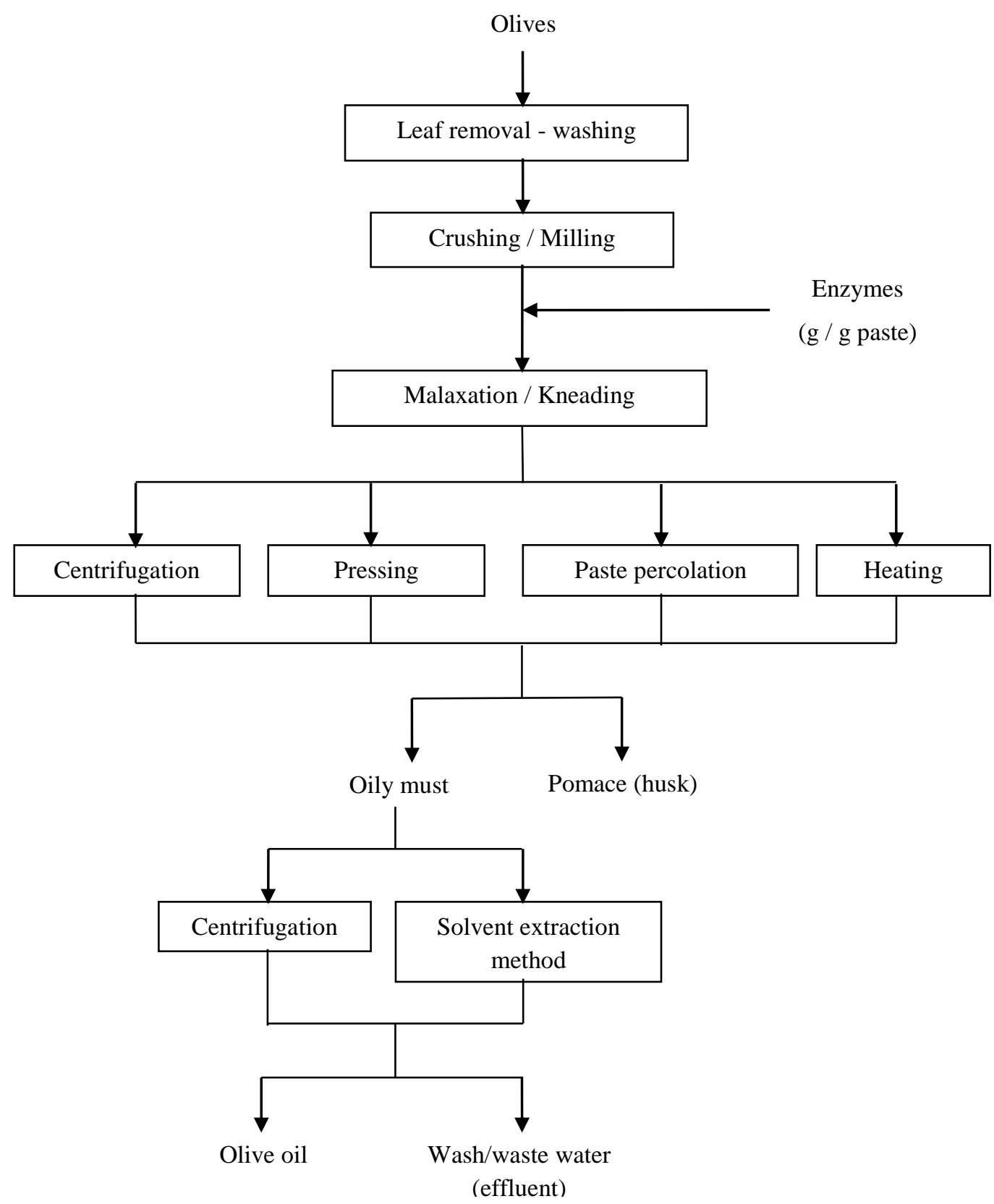

49

50

(b)

51

52

53

54 
58

59

60

61

62

63

64

65

66

67

68

69

70

71

72

73

74

75

76

77

78

7
Mature coconuts

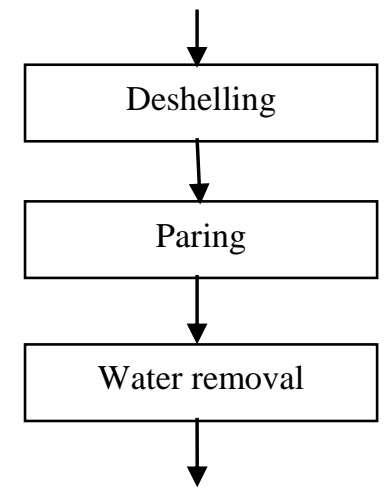

White coconut kernel
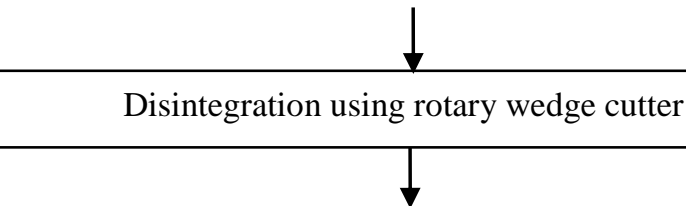

Grating: Expelling in a screw press

Coconut milk emulsion
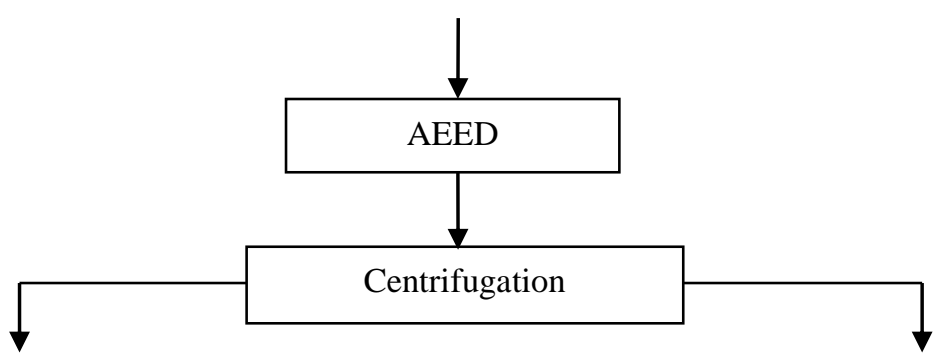

Aqueous phase

Coconut cream

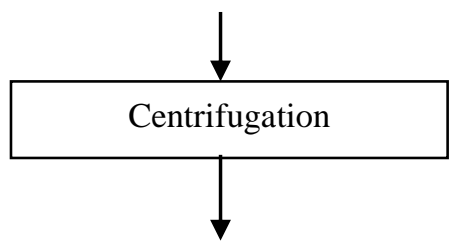

Virgin coconut oil

(c) 
Table 1. Commercial enzymes used for aqueous enzymatic extraction (AEE) and aqueous enzymatic emulsion de-emulsification (AEED) processes: descriptions and compositions.

\begin{tabular}{|c|c|c|}
\hline Enzymes commercial names & Description/Composition & Reference \\
\hline \multicolumn{3}{|l|}{ Single enzyme } \\
\hline Alcalase ${ }^{\circledR}$ & Protease & Womeni et al. (2008) \\
\hline \multirow[t]{6}{*}{ Alcalase $2.4 \mathrm{~L}$} & Protease & Rosenthal et al. (2001) \\
\hline & & Latif \& Anwar (2009) \\
\hline & & Jiang et al. (2010) \\
\hline & & Latif \& Anwar (2011) \\
\hline & & Rovaris et al. (2012) \\
\hline & & Tabtabaei \& Diosady (2013) \\
\hline As1398 & Protease & Jiang et al. (2010) \\
\hline \multirow[t]{6}{*}{ Celluclast $1.5 \mathrm{~L} \AA$} & Cellulase & Dominguez et al. (1996) \\
\hline & & Sineiro et al. (1998) \\
\hline & & Abdulkarim et al. (2006) \\
\hline & & Rovaris et al. (2012) \\
\hline & & Tabtabaei \& Diosady (2013) \\
\hline & & Teixeira et al. (2013) \\
\hline \multirow[t]{2}{*}{ Flavourzyme ${ }^{\circledR} 1000 \mathrm{~L}$} & Protease & Nyam et al. (2009) \\
\hline & & Nyam et al. (2009a) \\
\hline Glucanex & Glucosidases & Garcia et al. (2001) \\
\hline \multirow[t]{3}{*}{ G-ZYME® G999 } & Lysophospholipase A1 & Chabrand \& Glatz (2009) \\
\hline & & Wu et al. (2009) \\
\hline & & Tabtabaei \& Diosady (2013) \\
\hline Lipomod 699L & Phospholipase A2 & Tabtabaei \& Diosady (2013) \\
\hline LysoMax $^{\mathrm{TM}}$ & Phospholipase A2 & Wu et al. (2009) \\
\hline Multifect Neutral ${ }^{\circledR}$ & Protease & Lamsal \& Johnson (2007) \\
\hline \multirow[t]{4}{*}{ Neutrase $0.8 \mathrm{~L}$} & Bacterial neutral protease & Abdulkarim et al. (2005) \\
\hline & & Abdulkarim et al. (2006) \\
\hline & & Nyam et al. (2009) \\
\hline & & Nyam et al. (2009a) \\
\hline Nutrase & Xylanase & Jiang et al. (2010) \\
\hline Papain & Protease & Jiang et al. (2010) \\
\hline Pectinase 1.06021 & Pectinase & Najafian et al. (2009) \\
\hline Pectinase Multieffect FE® & Pectinase & Teixeira et al. (2013) \\
\hline
\end{tabular}




\begin{tabular}{|c|c|c|}
\hline Pectinex ${ }^{\circledR}$ & Pectinase & Womeni et al. (2008) \\
\hline Pectinex Ultra SP & Pectinase & Dominguez et al. (1996) \\
\hline \multirow[t]{2}{*}{ Pectinex Ultra SP-L } & Pectinase & Abdulkarim et al. (2006) \\
\hline & & Tabtabaei \& Diosady (2013) \\
\hline Promozyme & Pullulanase & Shah et al. (2005) \\
\hline Protamex & Protease & Jiang et al. (2010) \\
\hline \multirow[t]{6}{*}{ Protex 6L } & Alkaline serine endopeptidase & Chabrand \& Glatz (2009) \\
\hline & & Jung et al. (2009) \\
\hline & & Wu et al. (2009) \\
\hline & & Shan Liu et al. (2011) \\
\hline & & Xiaonan Sui et al. (2011) \\
\hline & & Tabtabaei \& Diosady (2013) \\
\hline \multirow[t]{7}{*}{ Protex 7L } & Natural metallo endopeptidase & Latif et al. (2008) \\
\hline & & Chabrand \& Glatz (2009) \\
\hline & & Jung \& Mahfuz (2009) \\
\hline & & Latif \& Anwar (2009) \\
\hline & & Wu et al. (2009) \\
\hline & & Latif \& Anwar (2011) \\
\hline & & Latif et al. (2011) \\
\hline Protex 30L & Alkaline serine endopeptidase & Chabrand \& Glatz (2009) \\
\hline Protex 50FP & $\begin{array}{l}\text { Acid fungal endopeptidase- } \\
\text { exopeptidase complex }\end{array}$ & Wu et al. (2009) \\
\hline \multirow[t]{2}{*}{ Protex 51FP } & Neutral fungal endopeptidase- & Wu et al. (2009) \\
\hline & exopeptidase complex & Tabtabaei \& Diosady (2013) \\
\hline Protex 89L & Endopeptidase & Tabtabaei \& Diosady (2013) \\
\hline ROHALASE® OS & Cellulase & Szydtowska-Czerniak et al. \\
\hline ROHAPECT® PTE & Pectinase & $(2010)$ \\
\hline Termamyl 120L & $\alpha$-amylase & Abdulkarim et al. (2006) \\
\hline \multicolumn{3}{|l|}{ Enzymes mixture } \\
\hline Bioliva & $\begin{array}{l}\text { Cellulase, hemicellulase, pectinase, } \\
\text { other minor enzymes }\end{array}$ & Ranalli et al. (2003) \\
\hline \multirow[t]{2}{*}{ Cytolase 0} & Cellulase, hemicellulase, pectinase, & Ranalli et al. (1999) \\
\hline & other minor enzymes & Ranalli et al. (2003) \\
\hline \multirow[t]{3}{*}{ Kemzyme } & Cellulase complex, hemi-cellulase & Latif \& Anwar (2009) \\
\hline & complex, $\alpha$-amylase, $\beta$-glucanase, & Latif \& Anwar (2011) \\
\hline & protease, xylanase & Latif et al. (2011) \\
\hline
\end{tabular}




\begin{tabular}{|c|c|c|}
\hline Maxoliva & $\begin{array}{l}\text { Cellulase, hemicellulase, pectinase, } \\
\text { other minor enzymes }\end{array}$ & Ranalli et al. (2003) \\
\hline Multifect CX 13L & $\begin{array}{l}\text { Cellulase, hemicellulase, } \beta \text {-glucanase, } \\
\text { arabinoxylans }\end{array}$ & $\begin{array}{l}\text { Latif et al. (2008) } \\
\text { Latif et al. (2011) }\end{array}$ \\
\hline Multifect Pectinase FE & Pectinase, cellulase, hemicellulase & Latif et al. (2008) \\
\hline Natuzyme & $\begin{array}{l}\text { Cellulase, xylanase, phytase, } \alpha- \\
\text { amylase, pectinase }\end{array}$ & $\begin{array}{l}\text { Latif et al. (2008) } \\
\text { Latif \& Anwar (2009) } \\
\text { Latif \& Anwar (2011) } \\
\text { Latif et al. (2011) }\end{array}$ \\
\hline Olivex & Cellulase, hemicellulase, pectinase & Garcia et al. (2001) \\
\hline Olivex-Celluclast & $\begin{array}{l}\text { 50\%: Cellulase, hemicellulase pectinase } \\
50 \% \text { : Cellulase, hemicellulase }\end{array}$ & Soto et al. (2007) \\
\hline Pectinex Ultra SP-L & Cellulase, pectinase, xylanase & $\begin{array}{l}\text { Shah et al. (2005) } \\
\text { Najafian et al. (2009) } \\
\text { Tabtabaei \& Diosady (2013) }\end{array}$ \\
\hline Protizyme $^{\mathrm{TM}}$ & $\begin{array}{l}\text { Three different proteases with } \mathrm{pH} \\
\text { optima } 3-4,5-7,7-10\end{array}$ & $\begin{array}{l}\text { Sharma et al. (2002) } \\
\text { Gaur et al. (2007) } \\
\text { Jiang et al. (2010) }\end{array}$ \\
\hline Rapidase ${ }^{\circledR}$ Liq plus & Hemicellulases, pectinases, cellulases & Gros et al. (2003) \\
\hline Viscozyme ${ }^{\circledR}$ & $\begin{array}{l}\text { (Carbohydrases): Cellulase, } \\
\text { hemicellulase, arabinase, xylanase, } \\
\text { amylase, } \beta \text {-glucanase }\end{array}$ & $\begin{array}{l}\text { Sowbhagya et al. (2009) } \\
\text { Womeni et al. (2008) }\end{array}$ \\
\hline Viscozyme L & $\begin{array}{l}\text { (Carbohydrases): Cellulase, } \\
\text { hemicellulase, arabinase, xylanase, } \beta \text { - } \\
\text { glucanase }\end{array}$ & $\begin{array}{l}\text { Latif \& Anwar (2009) } \\
\text { Latif \& Anwar (2011) } \\
\text { Latif } \text { et al. (2011) } \\
\text { Rovaris et al. (2012) } \\
\text { Tabtabaei \& Diosady (2013) }\end{array}$ \\
\hline
\end{tabular}


Table 2. Oil yield difference between the aqueous and aqueous enzymatic extraction, and between solvent and aqueous enzymatic extraction methods.

\begin{tabular}{|c|c|c|c|c|}
\hline \multirow[t]{2}{*}{ Oil-bearing material } & \multirow[t]{2}{*}{ Type of enzyme } & \multicolumn{2}{|c|}{ Difference in oil yield (\%) } & \multirow[t]{2}{*}{ Reference } \\
\hline & & $\begin{array}{l}\text { Aqueous extraction } \\
\text { and aqueous } \\
\text { enzymatic extraction }\end{array}$ & $\begin{array}{l}\text { Solvent treatment } \\
\text { and aqueous } \\
\text { enzymatic extraction }\end{array}$ & \\
\hline Crushed borage seeds $(\leq 2.0 \mathrm{~mm})$ & Olivex / Celluclast (1:1) & 7.80 & - & Soto et al. (2007) \\
\hline \multirow[t]{6}{*}{ Extruded soybean flakes } & Protease & 20.00 & - & Lamsal et al. (2006) \\
\hline & Multifect Neutral ${ }^{\circledR}$ & 13.40 & - & Lamsal \& Johnson (2007) \\
\hline & Protex 7L & 22.10 & - & Jung \& Mahfuz (2009) \\
\hline & Protex 51FP & $16.00^{\mathrm{a}}$ & - & Wu et al. (2009) \\
\hline & Protex 6L & $20.00^{\mathrm{a}}$ & - & \\
\hline & Protex 7L & $17.00^{\mathrm{a}}$ & - & \\
\hline \multirow[t]{3}{*}{ Ground canola seeds } & Multifect CX 13L & 9.50 & 17.10 & Latif et al. (2008) \\
\hline & Protex 7L & 6.90 & 19.70 & \\
\hline & Natuzyme & 6.20 & 20.40 & \\
\hline $\begin{array}{l}\text { Ground Jatropha seed kernels } \\
\text { (inedible) }\end{array}$ & Protizyme $^{\mathrm{TM}}$ & 26.00 & & Shah et al. (2005) \\
\hline \multirow[t]{2}{*}{ Ground Kalahari melon seeds } & Neutrase $0.8 \mathrm{~L}$ & & 9.58 & Nyam et al. (2009a) \\
\hline & Flavourzyme 1000L & & 8.67 & \\
\hline \multirow[t]{6}{*}{ Ground Moringa. oleifera seeds } & Neutrase $0.8 \mathrm{~L}$ & & 8.20 & Abdulkarim et al. (2005) \\
\hline & Neutrase $0.8 \mathrm{~L}$ & 12.12 & 9.39 & Abdulkarim et al. (2006) \\
\hline & Termamyl 120L & 10.15 & 11.36 & \\
\hline & Pectinex Ultra SP-L & 6.98 & 14.53 & \\
\hline & Celluclast $1.5 \mathrm{~L}$ & 10.12 & 11.39 & \\
\hline & $\begin{array}{l}\text { Neutrase 0.8L / Termamyl 120L / } \\
\text { Pectinex Ultra SP-L / Celluclast 1.5L }\end{array}$ & 12.83 & 8.68 & \\
\hline
\end{tabular}




\begin{tabular}{|c|c|c|c|c|}
\hline & Natuzyme & 9.10 & 23.30 & Latif et al. (2011) \\
\hline & Kemzyme & 10.30 & 22.10 & \\
\hline & Multifect CX 13L & 14.00 & 18.40 & \\
\hline & Protex 7L & 14.70 & 17.70 & \\
\hline & Viscozyme L & 13.10 & 19.30 & \\
\hline \multirow[t]{9}{*}{ Ground peanuts } & Alcalase & 42.86 & - & Jiang et al. (2010) \\
\hline & As1398 & 35.77 & - & \\
\hline & Nutrase & 29.49 & - & \\
\hline & Protizyme & 24.43 & - & \\
\hline & Protamex & 18.30 & - & \\
\hline & Protizyme $\mathrm{TM}^{\mathrm{TM}}$ & - & $3.36-5.88$ & Sharma et al. (2002) \\
\hline & Papain & - & 10.08 & \\
\hline & Chymotrypsin & - & 16.38 & \\
\hline & Trypsin & - & 13.86 & \\
\hline \multirow[t]{5}{*}{ Ground sesame seeds } & Alcalase $2.4 \mathrm{~L}$ & 12.50 & 25.40 & Latif \& Anwar (2011) \\
\hline & Natuzyme & 4.50 & 33.40 & \\
\hline & Protex 7L & 6.40 & 31.50 & \\
\hline & Viscozyme L & 9.10 & 28.80 & \\
\hline & Kemzyme & 4.20 & 33.70 & \\
\hline $\begin{array}{l}\text { Ground sunflower seeds }(0.75-1 \\
\mathrm{mm})\end{array}$ & Celluclast $1.5 \mathrm{~L}$ & 35.00 & - & Sineiro et al. (1998) \\
\hline \multirow[t]{5}{*}{ Ground sunflower seeds } & Alcalase $2.4 \mathrm{~L}$ & 8.30 & 18.90 & Latif \& Anwar (2009) \\
\hline & Kemzyme & 13.90 & 13.30 & \\
\hline & Natuzyme & 17.20 & 10.00 & \\
\hline & Protex 7L & 10.00 & 17.20 & \\
\hline & Viscozyme L & 21.40 & 5.80 & \\
\hline Heat-treated soybean flour & Alcalase $2.4 \mathrm{~L}$ & 16.90 & - & Rosenthal et al. (2001) \\
\hline
\end{tabular}




\begin{tabular}{|c|c|c|c|c|}
\hline \multirow[t]{3}{*}{ Kernel flour of bush mango } & Alcalase ${ }^{\circledR}$ & 7.60 & - & \multirow[t]{3}{*}{ Womeni et al. (2008) } \\
\hline & Pectinex ${ }^{\circledR}$ & 14.80 & - & \\
\hline & Viscozyme ${ }^{\circledR}$ & 40.60 & - & \\
\hline Minced yellow horn seed kernels & \multicolumn{2}{|l|}{$\begin{array}{l}\text { Cellulase / Hemicellulase / Pectinase } \\
(1.8: 1.3: 2.5)\end{array}$} & 9.00 & Li et al. (2013) \\
\hline \multirow[t]{7}{*}{ Olive paste } & Bioliva & 1.20 & - & \multirow[t]{3}{*}{ Ranalli et al. (2003) } \\
\hline & Maxoliva & 1.37 & - & \\
\hline & Cytolase 0 & 1.44 & - & \\
\hline & A (pectinase, cellulase, hemicellulase) & $152.00(30 \mathrm{~min})$ & - & \multirow[t]{2}{*}{ Aliakbarian et al. (2008) } \\
\hline & $\begin{array}{l}\text { / B (pectinase, hemicellulase) / } \\
\text { C (pectolytic enzyme) (1:1:1) }\end{array}$ & $91.40(150 \mathrm{~min})$ & - & \\
\hline & Pectinex Ultra SP-L & $1.96^{\mathrm{b}}$ & - & \multirow[t]{2}{*}{ Najafian et al. (2009) } \\
\hline & Pectinase 1.6021 & $1.41^{\mathrm{b}}$ & - & \\
\hline \multirow[t]{3}{*}{ Palm fruit } & Pectinase / cellulase & 35.57 & 5.36 & \multirow[t]{3}{*}{ Teixeira et al. (2013) } \\
\hline & Pectinase / cellulase / tannase & 35.90 & 5.03 & \\
\hline & Tannase & 12.70 & 28.23 & \\
\hline \multirow[t]{5}{*}{ Rapeseed slurry } & Pectinase & 38.10 & - & \multirow[t]{5}{*}{ Zhang et al. (2007) } \\
\hline & Cellulase & 21.50 & - & \\
\hline & B-glucanase & 16.20 & - & \\
\hline & $\begin{array}{l}\text { Pectinase / Cellulase / } \beta \text {-glucanase } \\
(4: 1: 1)\end{array}$ & 43.80 & - & \\
\hline & Multifect Pectinae FE & 5.70 & - & \\
\hline $\begin{array}{l}\text { Shattered bayberry kernels (60- } \\
\text { mesh sieved) }\end{array}$ & Cellulase / Neutral protease (1:2) & & 31.85 & Zhang et al. (2012) \\
\hline \multirow[t]{2}{*}{ Yellow mustard flour } & Celluclast $1.5 \mathrm{~L}$ & 3.74 & 10.59 & \multirow{2}{*}{$\begin{array}{l}\text { Tabtabaei \& Diosady } \\
\text { (2013) }\end{array}$} \\
\hline & Pectinex Ultra SP-L & 3.03 & 11.30 & \\
\hline
\end{tabular}




$\begin{array}{lll}\text { Viscozyme L } & 3.99 & 10.34 \\ \text { Celluclast 1.5L / Pectinex Ultra SP-L / } & 6.70 & 7.63 \\ \text { Viscozyme L (1: 1:1) } & & \end{array}$

The oil yield differences were determined based on the oil yields under the best incubating conditions of each enzyme used, or based on the fixed incubating conditions for all enzymes used, in the conducted studies.

All aqueous enzymatic extractions resulted in higher oil yields than aqueous extractions, and all solvent treatments resulted in higher oil yields than aqueous enzymatic extractions.

${ }^{a}$ total oil as in the skim and cream emulsion

$\mathrm{b}$ average oil yield enhancements from three olive species with the use of enzymes at high concentrations 
Table 3. Enhancement in oil yield due to presence of enzyme pre-treatment prior to the extraction method, as compared to the extraction method alone.

\begin{tabular}{|c|c|c|c|c|}
\hline Oil-bearing material & $\begin{array}{l}\text { Type of enzyme } \\
\text { (pre-treatment) }\end{array}$ & Extraction method & $\begin{array}{l}\text { Enhancement } \\
\text { in oil yield } \\
(\%)\end{array}$ & Reference \\
\hline $\begin{array}{l}\text { Crushed borage seeds } \\
(\leq 2.0 \mathrm{~mm})\end{array}$ & Olivex / Celluclast (1:1) & Double pressing & $5.40^{\mathrm{a}}$ & $\begin{array}{l}\text { Soto et al. } \\
(2007)\end{array}$ \\
\hline Crushed garlic cloves & $\begin{array}{l}\text { Cellulase } \\
\text { Pectinase } \\
\text { Protease } \\
\text { Viscozyme } \\
\text { Cellulase } \\
\text { Pectinase } \\
\text { Protease } \\
\text { Viscozyme }\end{array}$ & Steam distillation & $\begin{array}{l}0.11 \\
0.23 \\
0.22 \\
0.18 \\
0.14 \\
0.26 \\
0.24 \\
0.19\end{array}$ & $\begin{array}{l}\text { Sowbhagya et } \\
\text { al. (2009) }\end{array}$ \\
\hline Ground flaxseeds & $\begin{array}{l}\text { Cellulase / Pectinase / } \\
\text { Hemicellulase (1:1:1) }\end{array}$ & Ultrasonication & 29.50 & $\begin{array}{l}\text { Long et al. } \\
\text { (2011) }\end{array}$ \\
\hline Ground rapeseeds & $\begin{array}{l}\text { ROHAPECT® PTE } \\
\text { ROHALASE® OS }\end{array}$ & Pressing & $\begin{array}{l}5.70 \\
1.70\end{array}$ & $\begin{array}{l}\text { Szydtowska- } \\
\text { Czerniak et } \\
\text { al. (2010) }\end{array}$ \\
\hline Milled grape seeds & $\begin{array}{l}\text { A mixture of cellulase, } \\
\text { xylanase, protease, } \\
\text { pectinase }\end{array}$ & $\begin{array}{l}\text { Solvent extraction }(24 \mathrm{hr}) \\
\text { Solvent extraction }(120 \mathrm{hr})\end{array}$ & $\begin{array}{l}106.00 \\
163.00\end{array}$ & $\begin{array}{l}\text { Passos et al. } \\
\text { (2009) }\end{array}$ \\
\hline $\begin{array}{l}\text { Minced yellow horn seed } \\
\text { kernels }\end{array}$ & $\begin{array}{l}\text { Cellulase / hemicellulase / } \\
\text { pectinase }(1.8: 1.3: 2.5)\end{array}$ & Microwave & $\begin{array}{l}4.30 \text { (oil yield } \\
\text { enhancement } \\
\text { as compared to } \\
\text { AEE alone) }\end{array}$ & $\begin{array}{l}\text { Li et al. } \\
\text { (2013) }\end{array}$ \\
\hline $\begin{array}{l}\text { Pre-heated ground } \\
\text { Chilean hazelnut seeds } \\
\text { (inedible, } \leq 1.4 \mathrm{~mm} \text { ) }\end{array}$ & $\begin{array}{l}\text { Ultrazyme / Celluclast } \\
(1: 1)\end{array}$ & $\begin{array}{l}\text { Double pressing (hydraulic } \\
\text { pressing at each of } 39.2 \\
\mathrm{MPa} \text { ) }\end{array}$ & $\sim 8.00$ & $\begin{array}{l}\text { Zuniga et al. } \\
\text { (2003) }\end{array}$ \\
\hline $\begin{array}{l}\text { Silybum marianum seed } \\
\text { powders }\end{array}$ & $\begin{array}{l}\text { Cellulase / Xylanase / } \\
\text { Pectinase / Protease } \\
(2: 1: 1: 2)\end{array}$ & $\begin{array}{l}\text { Solvent extraction }(1.5 \mathrm{hr}) \\
\text { Solvent extraction }(14.0 \mathrm{hr})\end{array}$ & $\begin{array}{l}10.46 \\
50.72\end{array}$ & $\begin{array}{l}\text { Li et al. } \\
\text { (2012) }\end{array}$ \\
\hline Whole sunflower kernels & $\begin{array}{l}\text { Celluclast } 1.5 \mathrm{~L} / \text { Pectinex } \\
\text { Ultra SP }(2: 1)\end{array}$ & Pressing (Batch press) & 13.11 & $\begin{array}{l}\text { Dominguez et } \\
\text { al. (1996) }\end{array}$ \\
\hline $\begin{array}{l}\text { Mango kernel powders } \\
\text { Soybean flour }\end{array}$ & Protizyme $^{\mathrm{TM}}$ & $\begin{array}{l}\text { Three-phase partitioning } \\
\text { method }\end{array}$ & $\begin{array}{l}16.00 \\
8.00\end{array}$ & $\begin{array}{l}\text { Gaur et al. } \\
\text { (2007) }\end{array}$ \\
\hline
\end{tabular}


${ }^{a}$ the oil yield enhancement was based on the difference between an enzymatic and non-enzymatic pre-treatment, followed by double pressing 
Table 4. The advantages of the use of pre-treatments (non-enzymatic) prior to the enzymatic extraction method.

\begin{tabular}{|c|c|c|c|c|}
\hline $\begin{array}{l}\text { Oil-bearing } \\
\text { material }\end{array}$ & Pre-treatment & $\begin{array}{l}\text { Type of } \\
\text { enzyme }\end{array}$ & Advantages & Reference \\
\hline $\begin{array}{l}\text { Ground Isatis } \\
\text { indigotica } \\
\text { seeds }\end{array}$ & Microwave & $\begin{array}{l}\text { Cellulase / } \\
\text { Proteinase / } \\
\text { Pectinase } \\
(1: 1: 1)\end{array}$ & $\begin{array}{l}\text { - In combination with AEE, the use of } \\
\text { optimal microwave irradiation power } \\
\text { increased the oil yield up to } 59.27 \% \text {, and } \\
\text { the oil yield had greater antioxidant } \\
\text { properties than solvent-extracted oil. }\end{array}$ & Gai et al. (2013) \\
\hline $\begin{array}{l}\text { Ground } \\
\text { Jatropha seed } \\
\text { kernels } \\
\text { (inedible) }\end{array}$ & $\begin{array}{l}\text { Ultrasonication } \\
(5 \mathrm{~min})\end{array}$ & Protizyme $^{\mathrm{TM}}$ & $\begin{array}{l}\text { The enzyme treatment time was reduced } \\
\text { from } 18 \mathrm{hr} \text { to } 6 \mathrm{hr} \text { for maximum of } 74 \% \text { oil } \\
\text { yield }\end{array}$ & $\begin{array}{l}\text { Shah et al. } \\
\text { (2005) }\end{array}$ \\
\hline $\begin{array}{l}\text { Ground } \\
\text { linseeds }\end{array}$ & $\begin{array}{l}\text { Electrical } \\
\text { discharge }\end{array}$ & - & $\begin{array}{l}\text { Mucilage (stabilizing agent) is removed } \\
\text { which caused easier oil separation from the } \\
\text { resulted residue by using enzyme treatment }\end{array}$ & Gros et al. (2003) \\
\hline $\begin{array}{l}\text { Grounds } \\
\text { peanuts }\end{array}$ & $\begin{array}{l}\text { Alkaline } \\
\text { extraction }\end{array}$ & Alcalase & Oil yield of $5.87 \%$ higher than AEE alone & $\begin{array}{l}\text { Jiang et al. } \\
(2010)\end{array}$ \\
\hline $\begin{array}{l}\text { Ground pitaya } \\
\text { seeds (40- } \\
\text { mesh sieved) }\end{array}$ & Microwave & $\begin{array}{l}\text { Pectinase / } \\
\text { Cellulase / } \\
\text { Acid protease } \\
(1: 1: 1)\end{array}$ & $\begin{array}{l}\text { - Oil yield of } 0.84 \% \text { higher than AEE } \\
\text { alone }\end{array}$ & Rui et al. (2009) \\
\hline $\begin{array}{l}\text { Ground } \\
\text { watermelon } \\
\text { kernels }\end{array}$ & Ultrasound & Protex 6L & $\begin{array}{l}\text {-Under the fixed parameters of the } \\
\text { ultrasound, the yield was } 20.67 \% \text { higher } \\
\text { than AEE alone } \\
\text {-Under the selected parameters of } \\
\text { ultrasound for maximum oil yield, the } \\
\text { yield was } 21.39 \% \text { higher than AEE alone }\end{array}$ & $\begin{array}{l}\text { Xiaonan Sui et } \\
\text { al. (2011), Shan } \\
\text { Liu et al. (2011) }\end{array}$ \\
\hline \multirow[t]{3}{*}{$\begin{array}{l}\text { Soybean } \\
\text { flakes }\end{array}$} & $\begin{array}{l}\text { High pressure } \\
\text { processing }(200 \\
\mathrm{MPa})\end{array}$ & Protex 7L & Oil yield of $3.20 \%$ higher than AEE alone & $\begin{array}{l}\text { Jung \& Mahfuz } \\
\text { (2009) }\end{array}$ \\
\hline & $\begin{array}{l}\text { High pressure } \\
\text { processing }(500 \\
\mathrm{MPa})\end{array}$ & & Oil yield of $1.30 \%$ higher than AEE alone & \\
\hline & Extrusion & & $\begin{array}{l}\text { - Oil yield of } 29.90 \% \text { higher than AEE } \\
\text { alone } \\
\text { - Free oil yield of } 17.00 \% \text { higher than AEE }\end{array}$ & \\
\hline
\end{tabular}




\begin{tabular}{lll}
\hline \multirow{2}{*}{ Extrusion $\quad$ Protex 6L } & alone \\
& - Oil yield of 35.52\% higher than AEE $\quad$ Jung et al. (2009) \\
& alone \\
& - After de-emulsification: Free oil from \\
& cream emulsion of 62.00\% higher than \\
& AEE alone \\
\hline
\end{tabular}

AEE: aqueous enzymatic extraction. 
Table 5. Maximum oil yields as affected by the selected and optimized incubating conditions of the aqueous enzymatic extraction and aqueous enzymatic emulsion de-emulsification methods.

\begin{tabular}{|c|c|c|c|c|c|c|c|c|c|}
\hline Oil-bearing material & Type of enzyme & $\begin{array}{l}\text { Moisture / } \\
\text { Material ratio } \\
\text { (w/w; for } \\
\text { aqueous } \\
\text { enzymatic } \\
\text { extraction) }\end{array}$ & $\begin{array}{l}\text { Enzyme / } \\
\text { Material } \\
\text { ratio }\end{array}$ & pH & $\begin{array}{l}\text { Tempera- } \\
\text { ture }\left({ }^{\circ} \mathrm{C}\right)\end{array}$ & Time (hr) & $\begin{array}{l}\text { Agitation } \\
\text { rate (rpm) }\end{array}$ & $\begin{array}{l}\text { Oil yield } \\
(\%)\end{array}$ & Reference \\
\hline
\end{tabular}

Selected $(*)$ and optimized $(* *)$ incubating conditions used for maximum oil yield in aqueous enzymatic extraction

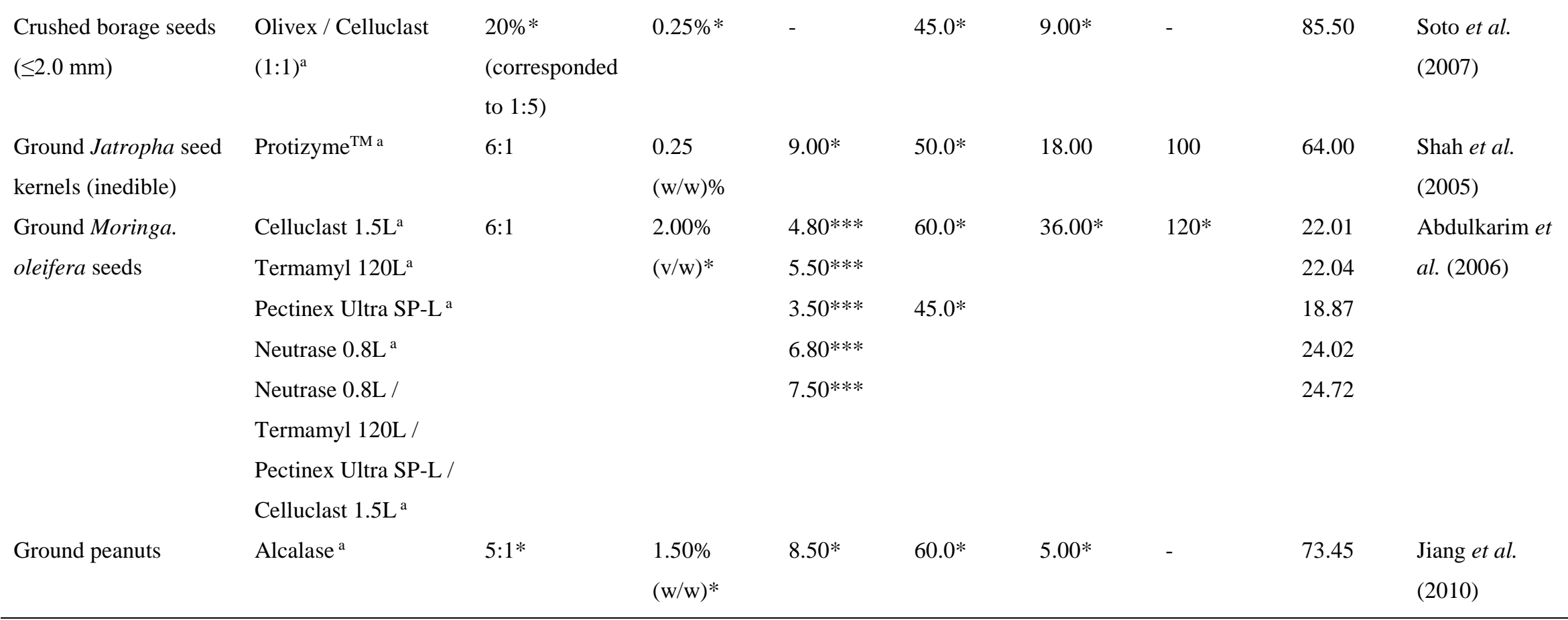




\begin{tabular}{|c|c|c|c|c|c|c|c|c|c|}
\hline & Protizyme $^{\mathrm{TM} \text { a }}$ & $2: 1$ & $\begin{array}{l}2.50 \% \\
(\mathrm{w} / \mathrm{w})^{*}\end{array}$ & $4.00 *$ & $40.0^{*}$ & $18.00^{*}$ & $80^{*}$ & $\begin{array}{l}36.12- \\
38.64\end{array}$ & $\begin{array}{l}\text { Sharma et al. } \\
\text { (2002) }\end{array}$ \\
\hline $\begin{array}{l}\text { Ground pitaya seeds } \\
\text { (40-mesh sieved) }\end{array}$ & $\begin{array}{l}\text { Pectinase / Cellulase / } \\
\text { Acid protease }(1: 1: 1) \\
\text { a }\end{array}$ & $8: 1$ & - & 7.00 & $50.0 *$ & 1.00 & 90 & 6.94 & $\begin{array}{l}\text { Rui et al. } \\
\text { (2009) }\end{array}$ \\
\hline $\begin{array}{l}\text { Ground rice bran } \\
\text { (16-mesh sieved) }\end{array}$ & Alcalase $0.6 \mathrm{~L}^{\mathrm{a}}$ & - & $\begin{array}{l}1.00 \% \\
(\mathrm{w} / \mathrm{w})^{*}\end{array}$ & 9.00 & $60.0^{*}$ & $3.00 *$ & 1000 & 79.10 & $\begin{array}{l}\text { Hanmoungjai } \\
\text { et al. (2001) }\end{array}$ \\
\hline $\begin{array}{l}\text { Ground sunflower } \\
\text { seeds }(0.75-1 \mathrm{~mm})\end{array}$ & Celluclast $1.5 \mathrm{~L}^{\mathrm{a}}$ & $5: 1^{*}$ & $\begin{array}{l}2.00 \% \\
(\mathrm{w} / \mathrm{w})^{*}\end{array}$ & $4.80^{* * *}$ & $50.0^{* * *}$ & $2.00^{*}$ & 150 & 35.65 & $\begin{array}{l}\text { Sineiro et al. } \\
\text { (1998) }\end{array}$ \\
\hline $\begin{array}{l}\text { Heat-treated soybean } \\
\text { flour }\end{array}$ & Alcalase $2.4 \mathrm{~L}^{\mathrm{a}}$ & - & $\begin{array}{l}3.00 \% \\
(\mathrm{v} / \mathrm{w})^{*}\end{array}$ & $8.00 * * *$ & $50.0^{* * *}$ & 1.00 & 200 & 58.70 & $\begin{array}{l}\text { Rosenthal et } \\
\text { al. (2001) }\end{array}$ \\
\hline Olive paste & $\begin{array}{l}\text { A (pectinase, } \\
\text { cellulase, } \\
\text { hemicellulase) / } \\
\text { B (pectinase, } \\
\text { hemicellulase) / } \\
\text { C (pectolytic } \\
\text { enzyme) }(1: 1: 1)^{a}\end{array}$ & - & $\begin{array}{l}0.25 \% \\
(\mathrm{v} / \mathrm{w})^{*}\end{array}$ & - & 30.0 & $\begin{array}{l}2 \mathrm{hr} 30 \\
\min *\end{array}$ & $\begin{array}{l}10 \\
\text { (kneading) }\end{array}$ & 17.50 & $\begin{array}{l}\text { Aliakbarian et } \\
\text { al. (2008) }\end{array}$ \\
\hline Rapeseed slurry & $\begin{array}{l}\text { Pectinase / Cellulase / } \\
\beta \text {-glucanase }(4: 1: 1)^{\mathrm{a}}\end{array}$ & $5: 1^{*}$ & $\begin{array}{l}2.50 \% \\
(\mathrm{v} / \mathrm{w})^{*}\end{array}$ & 5.00 & 48.0 & $4.00 *$ & 200 & 92.70 & $\begin{array}{l}\text { Zhang et al. } \\
\text { (2007) }\end{array}$ \\
\hline \multirow[t]{2}{*}{$\begin{array}{l}\text { Ground Kalahari } \\
\text { melon seeds }\end{array}$} & Neutrase $0.8 \mathrm{~L}^{\mathrm{a}}$ & - & $\begin{array}{l}2.50 \% \\
(\mathrm{w} / \mathrm{w})^{* *}\end{array}$ & $7.00 * *$ & $58.0 * *$ & $31.00^{* *}$ & 100 & 68.58 & $\begin{array}{l}\text { Nyam et al. } \\
(2009 a)\end{array}$ \\
\hline & $\begin{array}{l}\text { Flavourzyme }{ }^{\circledR} 1000 \\
\mathrm{~L}^{\mathrm{a}}\end{array}$ & - & $\begin{array}{l}2.10 \% \\
(\mathrm{w} / \mathrm{w})^{* *}\end{array}$ & $6.00 * *$ & $50.0 * *$ & $36.00 * *$ & 100 & 71.55 & \\
\hline $\begin{array}{l}\text { Ground Moringa. } \\
\text { oleifera seeds }\end{array}$ & Neutrase $0.8 \mathrm{~L}^{\mathrm{a}}$ & $6: 1(v / w)$ & $\begin{array}{l}2.00 \% \\
(\mathrm{v} / \mathrm{w})\end{array}$ & $6.80 * * *$ & $45.0 * *$ & $24.00 * *$ & 120 & 22.60 & $\begin{array}{l}\text { Abdulkarim et } \\
\text { al. (2005) }\end{array}$ \\
\hline
\end{tabular}




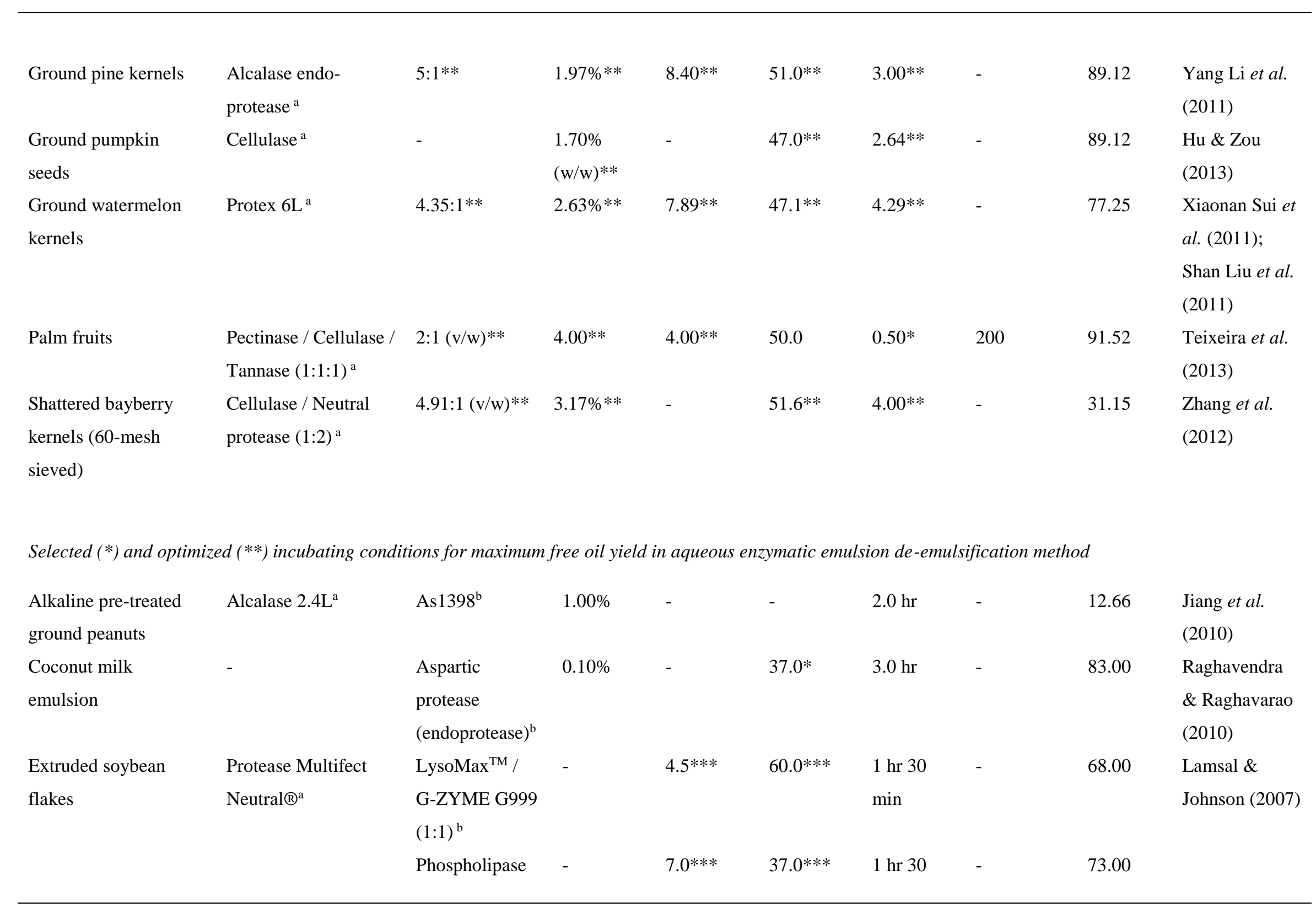




\begin{tabular}{|c|c|c|c|c|c|c|c|c|c|}
\hline & & $\mathrm{C}^{\mathrm{b}}$ & & & & $\min$ & & & \\
\hline & Protex $6 \mathrm{~L}^{\mathrm{a}}$ & Protex 6L ${ }^{b}$ & $2.50 \% *$ & $4.5^{*}$ & 50.0 & $\begin{array}{l}1 \mathrm{hr} 30 \\
\min \end{array}$ & - & 100.00 & $\begin{array}{l}\text { de Moura et al. } \\
(2008)\end{array}$ \\
\hline & Protex $6 \mathrm{~L}^{\mathrm{a}}$ & Protex 6L & $1.25 \% * *$ & - & $50.0 * *$ & $\begin{array}{l}1 \mathrm{hr} 30 \\
\min * *\end{array}$ & - & 100.00 & $\begin{array}{l}\text { Jung et al. } \\
\text { (2009) }\end{array}$ \\
\hline & Protex $7 \mathrm{~L}^{\mathrm{a}}$ & $\begin{array}{l}\text { LysoMax }^{\mathrm{TM} b} \\
\text { G-ZYME® }\end{array}$ & $2.00 \%$ & $\begin{array}{l}8.0 * * * \\
4.5 * * *\end{array}$ & $\begin{array}{l}40.0 * * * \\
50.0 * * *\end{array}$ & $\begin{array}{l}1 \mathrm{hr} 30 \\
\min \end{array}$ & - & 100.00 & $\begin{array}{l}\text { Wu et al. } \\
\text { (2009) }\end{array}$ \\
\hline & & G999b & & & & & & & \\
\hline & & Protex 6L $\mathrm{L}^{\mathrm{b}}$ & & $8.0 * * *$ & $50.0 * * *$ & & & & \\
\hline & & Protex 7L $\mathrm{L}^{\mathrm{b}}$ & & $7.0 * * *$ & $50.0 * * *$ & & & & \\
\hline & & Protex 50FP & & $4.5 * * *$ & $50.0 * * *$ & & & & \\
\hline & & Protex 51FP & & $8.0 * * *$ & $50.0 * * *$ & & & & \\
\hline $\begin{array}{l}\text { Ground Perilla } \\
\text { frutescens seeds }\end{array}$ & - & Protex 6L ${ }^{b}$ & $1.90 \% * *$ & $9.4 * *$ & $62.6 * *$ & $1.6 \mathrm{hr}^{* *}$ & - & 85.52 & $\begin{array}{l}\text { Zhang et al. } \\
\text { (2013) }\end{array}$ \\
\hline \multirow[t]{2}{*}{ Soybean flour } & Protex $7 \mathrm{~L}^{\mathrm{a}}$ & $\begin{array}{l}\text { G-ZYME } \\
\text { G999b }\end{array}$ & $2.00 \% *$ & $4.5 * * *$ & 50.0 & $3.0 \mathrm{hr}$ & $700 *$ & 100.00 & $\begin{array}{l}\text { Chabrand \& } \\
\text { Glatz (2009) }\end{array}$ \\
\hline & & Protex 6L $\mathrm{L}^{\mathrm{b}}$ & $3.00 \% *$ & $9.0 * * *$ & 50.0 & $3.0 \mathrm{hr}$ & $500^{*}$ & 72.00 & \\
\hline \multirow[t]{6}{*}{ Yellow mustard flour } & Celluclast 1.5L / & Protex 6L $\mathrm{L}^{\mathrm{b}}$ & $2.50 \%$ & $4.5-$ & $50-60 * * *$ & $3.0 \mathrm{hr}$ & - & 91.30 & Tabtabaei \& \\
\hline & Viscozyme L / & & & $6.0 * * *$ & & & & & Diosady \\
\hline & Pectinex Ultra SP-L & Alcalase $2.4 \mathrm{~L}^{\mathrm{b}}$ & & $6.5-$ & $45-65^{* * *}$ & & & 42.10 & (2013) \\
\hline & $(1: 1: 1)^{\mathrm{a}}$ & & & $8.5 * * *$ & & & & & \\
\hline & & Lipomode & & $8.0 * * *$ & $40.0^{* * *}$ & & & 1.30 & \\
\hline & & $699 \mathrm{~L}^{\mathrm{b}}$ & & & & & & & \\
\hline
\end{tabular}




\section{G-ZYME}

$4.5 * * *$

$50-60 * * *$

41.20

G999

Values without any notation are fixed incubating conditions.

${ }^{a}$ Type of enzymes used for aqueous enzymatic extraction

$\mathrm{b}$ Type of enzymes used for aqueous enzymatic emulsion de-emulsification

*selected incubating condition; the authors varied the level of each incubating condition and finalized the conditions which resulted in highest oil yield.

**optimized incubating condition; the authors varied the level of each incubating condition and optimized the conditions which resulted in highest oil yield based on an experimental design and statistical software used.

*** optimum incubating condition of the enzyme used; different types of enzymes possess different optimum pH and temperature where the enzymes attain maximum activity 
Table 6. The characteristics of oil yields from solvent, aqueous, and aqueous enzymatic extraction methods.

\begin{tabular}{|c|c|c|c|c|c|c|}
\hline $\begin{array}{l}\text { Oil } \\
\text { characteris- } \\
\text { tic }\end{array}$ & Oil-bearing material & $\begin{array}{l}\text { Solvent } \\
\text { extraction }\end{array}$ & $\begin{array}{l}\text { Aqueous } \\
\text { extraction }\end{array}$ & Aque & enzymatic extraction & Reference \\
\hline \multirow[t]{28}{*}{$\begin{array}{l}\text { Free fatty } \\
\text { acids }(\%)\end{array}$} & $\begin{array}{l}\text { Extruded soybean } \\
\text { flakes }\end{array}$ & 0.26 & * & 0.18 & Protex 6L & $\begin{array}{l}\text { Jung et al. } \\
\text { (2009) }\end{array}$ \\
\hline & Ground canola seeds & 0.81 & 0.56 & 0.52 & Multifect CX 13L & Latif et al. \\
\hline & & & & 0.57 & Protex 7L & (2008) \\
\hline & & & & 0.55 & Natuzyme & \\
\hline & & & & 0.54 & Multifect Pectinae FE & \\
\hline & $\begin{array}{l}\text { Ground Kalahari } \\
\text { melon seeds }\end{array}$ & 0.60 & $*$ & $\begin{array}{l}0.90 \\
0.90\end{array}$ & $\begin{array}{l}\text { Flavourzyme }{ }^{\circledR} 1000 \mathrm{~L} \\
\text { Neutrase } 0.8 \mathrm{~L}\end{array}$ & $\begin{array}{l}\text { Nyam et al. } \\
\text { (2009) }\end{array}$ \\
\hline & $\begin{array}{l}\text { Ground Moringa. } \\
\text { oleifera seeds }\end{array}$ & 2.48 & $*$ & 1.13 & Neutrase $0.8 \mathrm{~L}$ & $\begin{array}{l}\text { Abdulkarim } \\
\text { et al. (2005) }\end{array}$ \\
\hline & & 2.48 & 1.22 & 1.13 & Neutrase $0.8 \mathrm{~L}$ & Abdulkarim \\
\hline & & & & 1.24 & Termamyl 120L & et al. (2006) \\
\hline & & & & 1.22 & Pectinex Ultra SP-L & \\
\hline & & & & 1.25 & Celluclast $1.5 \mathrm{~L}$ & \\
\hline & & & & 1.23 & Neutrase $0.8 \mathrm{~L} /$ & \\
\hline & & & & & Termamyl 120L / & \\
\hline & & & & & Pectinex Ultra SP-L / & \\
\hline & & & & & Celluclast $1.5 \mathrm{~L}$ & \\
\hline & & 1.26 & 0.42 & 0.43 & Natuzyme & Latif et al. \\
\hline & & & & 0.41 & Kemzyme & (2011) \\
\hline & & & & 0.39 & Multifect CX 13L & \\
\hline & & & & 0.38 & Protex 7L & \\
\hline & & & & 0.42 & Viscozyme L & \\
\hline & $\begin{array}{l}\text { Ground rice bran (16- } \\
\text { mesh sieved) }\end{array}$ & 7.40 & $*$ & 2.36 & Alcalase $0.6 \mathrm{~L}$ & $\begin{array}{l}\text { Hanmoungjai } \\
\text { et al. (2001) }\end{array}$ \\
\hline & Ground sesame seeds & $0.54 \mathrm{c}$ & 0.48 & 0.47 & Natuzyme & Latif \& \\
\hline & & & & 0.44 & Kemzyme & Anwar (2011) \\
\hline & & & & 0.51 & Protex 7L & \\
\hline & & & & 0.46 & Alcalase $2.4 \mathrm{~L}$ & \\
\hline & & & & 0.44 & Viscozyme L & \\
\hline & Ground sunflower & 0.94 & 0.68 & 0.66 & Alcalase $2.4 \mathrm{~L}$ & Latif \& \\
\hline & seeds & & & 0.65 & Kemzyme & Anwar (2009) \\
\hline
\end{tabular}




\begin{tabular}{|c|c|c|c|c|c|c|}
\hline & & & & 0.67 & Natuzyme & \\
\hline & & & & 0.69 & Protex 7L & \\
\hline & & & & 0.64 & Viscozyme L & \\
\hline \multirow{28}{*}{$\begin{array}{l}\text { Iodine value } \\
(\mathrm{g} / 100 \mathrm{~g})\end{array}$} & Ground canola seeds & 117.00 & 114.00 & 116.00 & Multifect CX 13L & Latif et al. \\
\hline & & & & 114.00 & Protex 7L & $(2008)$ \\
\hline & & & & 117.00 & Natuzyme & \\
\hline & & & & 116.00 & Multifect Pectinae FE & \\
\hline & Ground flaxseeds & 140.80 & $*$ & 161.20 & $\begin{array}{l}\text { Cellulase / Pectinase / } \\
\text { Hemicellulase (1:1:1) }\end{array}$ & $\begin{array}{l}\text { Long et al. } \\
\text { (2011) }\end{array}$ \\
\hline & $\begin{array}{l}\text { Ground Kalahari } \\
\text { melon seeds }\end{array}$ & 125.00 & $*$ & $\begin{array}{l}141.00 \\
135.20\end{array}$ & $\begin{array}{l}\text { Flavourzyme } ₫ 1000 \mathrm{~L} \\
\text { Neutrase } 0.8 \mathrm{~L}\end{array}$ & $\begin{array}{l}\text { Nyam et al. } \\
(2009)\end{array}$ \\
\hline & $\begin{array}{l}\text { Ground Moringa. } \\
\text { oleifera } \text { seeds }\end{array}$ & 65.40 & $*$ & 66.10 & Neutrase $0.8 \mathrm{~L}$ & $\begin{array}{l}\text { Abdulkarim } \\
\text { et al. }(2005)\end{array}$ \\
\hline & & 65.40 & 66.00 & 67.10 & Neutrase $0.8 \mathrm{~L}$ & Abdulkarim \\
\hline & & & & 66.50 & Termamyl 120L & et al. (2006) \\
\hline & & & & 67.20 & Pectinex Ultra SP-L & \\
\hline & & & & 66.50 & Celluclast $1.5 \mathrm{~L}$ & \\
\hline & & & & 67.00 & Neutrase $0.8 \mathrm{~L} /$ & \\
\hline & & & & & Termamyl 120L / & \\
\hline & & & & & Pectinex Ultra SP-L / & \\
\hline & & & & & Celluclast $1.5 \mathrm{~L}$ & \\
\hline & & 67.00 & 70.00 & 76.00 & Natuzyme & Latif et al. \\
\hline & & & & 73.00 & Kemzyme & $(2011)$ \\
\hline & & & & 75.00 & Multifect CX 13L & \\
\hline & & & & 74.00 & Protex 7L & \\
\hline & & & & 76.00 & Viscozyme L & \\
\hline & $\begin{array}{l}\text { Ground pitaya seeds } \\
\text { (40-mesh sieved) }\end{array}$ & 173.10 & $*$ & 118.00 & $\begin{array}{l}\text { Pectinase / Cellulase / } \\
\text { Acid protease (1:1:1) }\end{array}$ & $\begin{array}{l}\text { Rui et al. } \\
\text { (2009) }\end{array}$ \\
\hline & $\begin{array}{l}\text { Ground rice bran (16- } \\
\text { mesh sieved) }\end{array}$ & 95.40 & $*$ & 97.18 & Alcalase $0.6 \mathrm{~L}$ & $\begin{array}{l}\text { Hanmoungjai } \\
\text { et al. }(2001)\end{array}$ \\
\hline & Ground sesame seeds & 107.00 & 106.00 & 104.00 & Natuzyme & Latif \& \\
\hline & & & & 109.00 & Kemzyme & Anwar (2011) \\
\hline & & & & 108.00 & Protex 7L & \\
\hline & & & & 105.00 & Alcalase $2.4 \mathrm{~L}$ & \\
\hline & & & & 103.00 & Viscozyme L & \\
\hline & Ground sunflower & 127.00 & 120.00 & 124.00 & Alcalase $2.4 \mathrm{~L}$ & Latif \& \\
\hline
\end{tabular}




\begin{tabular}{|c|c|c|c|c|c|c|}
\hline & seeds & & & 121.00 & Kemzyme & Anwar (2009) \\
\hline & & & & 123.00 & Natuzyme & \\
\hline & & & & 122.00 & Protex 7L & \\
\hline & & & & 121.00 & Viscozyme L & \\
\hline $\begin{array}{l}\text { Peroxide } \\
\text { value (meq }\end{array}$ & $\begin{array}{l}\text { Extruded soybean } \\
\text { flakes }\end{array}$ & 6.50 & $*$ & 4.05 & Protex 6L & $\begin{array}{l}\text { Jung et al. } \\
\text { (2009) }\end{array}$ \\
\hline $\left.\mathrm{O}_{2} / \mathrm{kg}\right)$ & Ground canola seeds & 1.29 & 0.69 & 0.72 & Multifect CX 13L & Latif et al. \\
\hline & & & & 0.70 & Protex 7L & (2008) \\
\hline & & & & 0.71 & Natuzyme & \\
\hline & & & & 0.64 & Multifect Pectinae FE & \\
\hline & Ground flaxseeds & 1.20 & $*$ & 1.00 & Cellulase / Pectinase / & Long et al. \\
\hline & & & & & Hemicellulase (1:1:1) & (2011) \\
\hline & Ground Kalahari & 2.30 & $*$ & 6.40 & Flavourzyme ${ }^{\circledR} 1000 \mathrm{~L}$ & Nyam et al. \\
\hline & melon seeds & & & 7.30 & Neutrase $0.8 \mathrm{~L}$ & (2009) \\
\hline & Ground Moringa. & 2.09 & 1.60 & 1.58 & Natuzyme & Latif et al. \\
\hline & oleifera seeds & & & 1.56 & Kemzyme & (2011) \\
\hline & & & & 1.61 & Multifect CX 13L & \\
\hline & & & & 1.63 & Protex 7L & \\
\hline & & & & 1.59 & Viscozyme L & \\
\hline & Ground pitaya seeds & 1.93 & $*$ & 1.44 & Pectinase / Cellulase / & Rui et al. \\
\hline & (40-mesh sieved) & & & & Acid protease $(1: 1: 1)$ & (2005) \\
\hline & $\begin{array}{l}\text { Ground rice bran (16- } \\
\text { mesh sieved) }\end{array}$ & 8.20 & $*$ & 12.01 & Alcalase $0.6 \mathrm{~L}$ & $\begin{array}{l}\text { Hanmoungjai } \\
\text { et al. (2001) }\end{array}$ \\
\hline & Ground sesame seeds & 1.50 & 1.30 & 0.90 & Natuzyme & Latif \& \\
\hline & & & & 1.30 & Kemzyme & Anwar (2011) \\
\hline & & & & 1.40 & Protex 7L & \\
\hline & & & & 1.10 & Alcalase $2.4 \mathrm{~L}$ & \\
\hline & & & & 1.20 & Viscozyme L & \\
\hline & Ground sunflower & 1.78 & 1.36 & 1.25 & Alcalase $2.4 \mathrm{~L}$ & Latif \& \\
\hline & seeds & & & 1.33 & Kemzyme & Anwar (2009) \\
\hline & & & & 1.32 & Natuzyme & \\
\hline & & & & 1.31 & Protex 7L & \\
\hline & & & & 1.37 & Viscozyme L & \\
\hline Saponifica- & Ground Kalahari & 173.20 & $*$ & 185.20 & Flavourzyme ${ }^{\circledR} 1000 \mathrm{~L}$ & Nyam et al. \\
\hline tion value & melon seeds & & & 184.80 & Neutrase $0.8 \mathrm{~L}$ & (2009) \\
\hline
\end{tabular}




\begin{tabular}{|c|c|c|c|c|c|c|}
\hline $\begin{array}{l}\text { (mg KOH / g } \\
\text { oil) }\end{array}$ & $\begin{array}{l}\text { Ground Moringa. } \\
\text { oleifera } \text { seeds }\end{array}$ & 164.00 & * & 163.00 & Neutrase $0.8 \mathrm{~L}$ & $\begin{array}{l}\text { Abdulkarim } \\
\text { et al. }(2005)\end{array}$ \\
\hline & & 164.00 & 158.00 & $\begin{array}{l}156.00 \\
158.00 \\
155.00 \\
159.00 \\
156.00\end{array}$ & $\begin{array}{l}\text { Natuzyme } \\
\text { Kemzyme } \\
\text { Multifect CX 13L } \\
\text { Protex 7L } \\
\text { Viscozyme L }\end{array}$ & $\begin{array}{l}\text { Latif et al. } \\
\text { (2011) }\end{array}$ \\
\hline & $\begin{array}{l}\text { Ground pitaya seeds } \\
\text { (40-mesh sieved) }\end{array}$ & 194.40 & * & 191.10 & $\begin{array}{l}\text { Pectinase / Cellulase / } \\
\text { Acid protease (1:1:1) }\end{array}$ & $\begin{array}{l}\text { Rui et al. } \\
\text { (2005) }\end{array}$ \\
\hline & $\begin{array}{l}\text { Ground rice bran (16- } \\
\text { mesh sieved) }\end{array}$ & 187.60 & $*$ & 188.72 & Alcalase 0.6L & $\begin{array}{l}\text { Hanmoungjai } \\
\text { et al. }(2001)\end{array}$ \\
\hline & Ground sesame seeds & 169.00 & 159.00 & $\begin{array}{l}158.00 \\
162.00 \\
167.00 \\
164.00 \\
156.00\end{array}$ & $\begin{array}{l}\text { Natuzyme } \\
\text { Kemzyme } \\
\text { Protex 7L } \\
\text { Alcalase } 2.4 \mathrm{~L} \\
\text { Viscozyme L }\end{array}$ & $\begin{array}{l}\text { Latif \& } \\
\text { Anwar (2011) }\end{array}$ \\
\hline & $\begin{array}{l}\text { Ground sunflower } \\
\text { seeds }\end{array}$ & 190.00 & 187.00 & $\begin{array}{l}187.00 \\
186.00 \\
187.00 \\
187.00 \\
185.00\end{array}$ & $\begin{array}{l}\text { Alcalase } 2.4 \mathrm{~L} \\
\text { Kemzyme } \\
\text { Natuzyme } \\
\text { Protex 7L } \\
\text { Viscozyme L }\end{array}$ & $\begin{array}{l}\text { Latif \& } \\
\text { Anwar (2009) }\end{array}$ \\
\hline $\begin{array}{l}\text { Total } \\
\text { tocopherols; } \\
\alpha, \delta \text {, and } \gamma \\
(\alpha, \beta, \delta \text {, and } \gamma\end{array}$ & Ground canola seeds & 739.00 & 598.00 & $\begin{array}{l}794.00 \\
805.00 \\
783.00 \\
819.00\end{array}$ & $\begin{array}{l}\text { Multifect CX 13L } \\
\text { Protex 7L } \\
\text { Natuzyme } \\
\text { Multifect Pectinae FE }\end{array}$ & $\begin{array}{l}\text { Latif et al. } \\
\text { (2008) }\end{array}$ \\
\hline $\begin{array}{l}\text { for Kalahari } \\
\text { melon seeds }\end{array}$ & $\begin{array}{l}\text { Ground Kalahari } \\
\text { melon seeds }\end{array}$ & 174.80 & $*$ & $\begin{array}{l}143.20 \\
143.30\end{array}$ & $\begin{array}{l}\text { Flavourzyme }{ }^{\circledR} 1000 \mathrm{~L} \\
\text { Neutrase } 0.8 \mathrm{~L}\end{array}$ & $\begin{array}{l}\text { Nyam et al. } \\
(2009)\end{array}$ \\
\hline $\begin{array}{l}\text { and olive } \\
\text { paste) } \\
\text { (mg / kg oil) }\end{array}$ & $\begin{array}{l}\text { Ground Moringa } \\
\text { oleifera seeds }\end{array}$ & 179.30 & 216.90 & $\begin{array}{l}220.80 \\
228.50 \\
221.70 \\
221.50 \\
228.30\end{array}$ & $\begin{array}{l}\text { Natuzyme } \\
\text { Kemzyme } \\
\text { Multifect CX 13L } \\
\text { Protex 7L } \\
\text { Viscozyme L }\end{array}$ & $\begin{array}{l}\text { Latif et al. } \\
(2011)\end{array}$ \\
\hline & Ground sesame seeds & 584.10 & 603.30 & $\begin{array}{l}628.50 \\
641.20 \\
627.30 \\
619.80\end{array}$ & $\begin{array}{l}\text { Natuzyme } \\
\text { Kemzyme } \\
\text { Protex 7L } \\
\text { Alcalase 2.4L }\end{array}$ & $\begin{array}{l}\text { Latif \& } \\
\text { Anwar (2011) }\end{array}$ \\
\hline
\end{tabular}




\begin{tabular}{|c|c|c|c|c|c|c|c|}
\hline & & & & & 612.80 & Viscozyme L & \\
\hline & Grounc & unflower & 799.00 & 778.00 & 845.00 & Alcalase $2.4 \mathrm{~L}$ & Latif \& \\
\hline & seeds & & & & 849.00 & Kemzyme & Anwar (2009) \\
\hline & & & & & 849.00 & Natuzyme & \\
\hline & & & & & 842.00 & Protex 7L & \\
\hline & & & & & 833.00 & Viscozyme L & \\
\hline & Olive & Cipressino & $*$ & 77.30 & 89.20 & Cytolase 0 & Ranalli et al. \\
\hline & paste & Cassanese & & 95.20 & 114.10 & & (2001) \\
\hline & & Leccino & & 117.00 & 135.40 & & \\
\hline & & Dritta & $*$ & 231.00 & 288.00 & Cytolase 0 & Ranalli et al. \\
\hline & & & & & 279.00 & Maxoliva & (2003) \\
\hline & & & & & 266.00 & Bioliva & \\
\hline & & Caroleo & $*$ & 218.00 & 273.00 & Cytolase 0 & \\
\hline & & & & & 269.00 & Maxoliva & \\
\hline & & & & & 252.00 & Bioliva & \\
\hline & & Coratina & $*$ & 244.00 & 305.00 & Cytolase 0 & \\
\hline & & & & & 300.00 & Maxoliva & \\
\hline & & & & & 289.00 & Bioliva & \\
\hline & Palm fr & & $*$ & 325.27 & 251.11 & Pectinase / Cellulase & Teixeira et al. \\
\hline & & & & & 200.54 & Pectinase / Cellulase / & (2013) \\
\hline & & & & & & Tannase & \\
\hline & & & & & 204.26 & Tannase & \\
\hline Total & Grounc & Kalahari & 18.00 & $*$ & 18.00 & Flavourzyme ${ }^{\circledR} 1000 \mathrm{~L}$ & Nyam et al. \\
\hline phenolic & melon & & & & 19.00 & Neutrase $0.8 \mathrm{~L}$ & (2009) \\
\hline content & Grounc & Moringa & 12.00 & 13.00 & 15.00 & Natuzyme & Latif et al. \\
\hline (mg / kg oil), & oleiferc & seeds & & & 14.00 & Kemzyme & (2011) \\
\hline as in gallic & & & & & 13.00 & Multifect CX 13L & \\
\hline acid & & & & & 14.00 & Protex 7L & \\
\hline equivalent for & & & & & 18.00 & Viscozyme L & \\
\hline sesame seeds, & Grounc & esame seeds & 17.00 & 18.00 & 19.00 & Natuzyme & Latif \& \\
\hline sunflower & & & & & 18.00 & Kemzyme & Anwar (2011) \\
\hline seeds, & & & & & 22.00 & Protex 7L & \\
\hline Moringa & & & & & 21.00 & Alcalase $2.4 \mathrm{~L}$ & \\
\hline oleifera & & & & & 24.00 & Viscozyme L & \\
\hline seeds, and & Grounc & unflower & 8.00 & 9.00 & 13.00 & Alcalase $2.4 \mathrm{~L}$ & Latif \& \\
\hline palm fruit; & seeds & & & & 14.00 & Kemzyme & Anwar (2009) \\
\hline
\end{tabular}




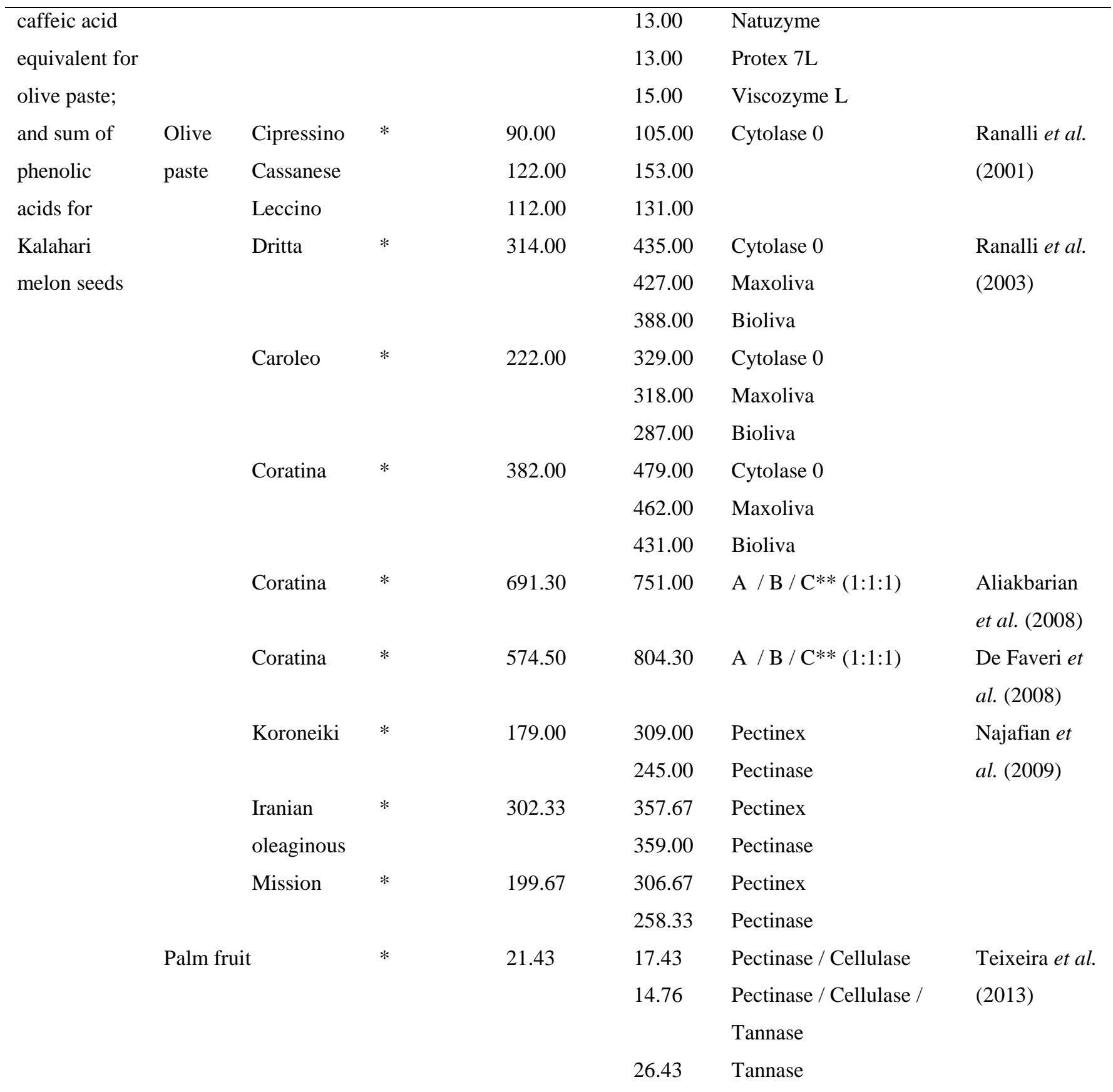

The column adjacent to the olive paste refers to the different olive species used.

*data not reported

**A: pectinase, cellulase, hemicellulase; B: pectinase, hemicellulase; C: pectolytic enzyme 